Review

\title{
Root Exudation: The Ecological Driver of Hydrocarbon Rhizoremediation
}

\author{
Fanny Rohrbacher and Marc St-Arnaud * \\ Biodiversity Center, Institut de recherche en biologie végétale, Université de Montréal and Jardin botanique de \\ Montréal, Montréal, QC H1X 2B2, Canada; fanny.rohrbacher@umontreal.ca \\ * Correspondence: marc.st-arnaud@umontreal.ca; Tel.: +1-514-872-1439; Fax: +1-514-343-2288 \\ Academic Editors: Leslie A. Weston and Xiaocheng Zhu \\ Received: 4 December 2015; Accepted: 4 March 2016; Published: 9 March 2016
}

\begin{abstract}
Rhizoremediation is a bioremediation technique whereby microbial degradation of organic contaminants occurs in the rhizosphere. It is considered to be an effective and affordable "green technology" for remediating soils contaminated with petroleum hydrocarbons. Root exudation of a wide variety of compounds (organic, amino and fatty acids, carbohydrates, vitamins, nucleotides, phenolic compounds, polysaccharides and proteins) provide better nutrient uptake for the rhizosphere microbiome. It is thought to be one of the predominant drivers of microbial communities in the rhizosphere and is therefore a potential key factor behind enhanced hydrocarbon biodegradation. Many of the genes responsible for bacterial adaptation in contaminated soil and the plant rhizosphere are carried by conjugative plasmids and transferred among bacteria. Because root exudates can stimulate gene transfer, conjugation in the rhizosphere is higher than in bulk soil. A better understanding of these phenomena could thus inform the development of techniques to manipulate the rhizosphere microbiome in ways that improve hydrocarbon bioremediation.
\end{abstract}

Keywords: rhizosphere microbiome; root exudates; biodegradation; hydrocarbon; lateral gene transfer; plasmid

\section{Introduction}

Since the nineteenth century, the industrial production of chemicals (including their improper use, incorrect elimination and accidental losses) has caused pollution of many environments. The loss of crude oil was estimated at 600,000 tonnes $( \pm 200,000)$ per year worldwide [1,2]. Anthropogenic substances that cause serious ecotoxicological problems include halogenated aromatic compounds, polycyclic aromatic hydrocarbons (PAHs) and BTEX (benzene, ethylbenzene, toluene and xylene) [3]. PAHs are frequently found in the soil environment at relatively large concentrations (hundreds of $\mathrm{mg} \cdot \mathrm{kg}^{-1}$ ) [4-6]. The main sources of these toxic substances are oil refineries, gas stations, agrochemical, petrochemical and pharmaceutical industries. In addition to harming the sustainability of various ecosystems, the presence of these pollutants in the environment has posed a danger to public health due to their toxicity, their mutagenic and carcinogenic properties, and their ability to accumulate in the food chain [3,7]. Most aromatic compounds are recalcitrant and persist in the environment for long periods of time. Cleaning up these environments has become a major environmental and health issue.

In Canada alone, 30,000 contaminated sites have been identified [8] and their rehabilitation could cost billions of dollars using standard approaches (these consist of soil excavation and transportation to a landfill, commonly referred as the "dig-and-dump" strategy). Due to the prohibitive cost of standard strategies, a high proportion of contaminated sites are either left as is or the rehabilitation is postponed. Thus, others alternatives are clearly required. Biological techniques of remediation, called bioremediation, directly benefit from the ability of some organisms (plants, fungi and bacteria) to sequester, concentrate and/or degrade contaminants [9]. Bioremediation is considered to be a "green" 
approach that is one of the prospects for sustainable development. Bioremediation helps to clean up the sites that are inaccessible to the excavation or that do not allow for the high cost required for standard strategies, does not require transportation of contaminated soil and requires less labor, is less expensive and has a lower carbon footprint (amount of $\mathrm{CO}_{2}$ emitted) than traditional techniques of remediation [9]. Current rehabilitation costs can total over $\$ 1$ million per hectare and some studies have indicated that implementing phytoremediation may result in a cost savings of 50 to 80 percent over traditional technologies [10-13].

Phytoremediation is the direct use of living plants for in situ bioremediation of contaminated environments, such as soils [14,15]. This technique can be used to clean up sites with shallow, low to moderate levels of various contaminants, such as hydrocarbons [14,16-19]. It is a promising technique which saves biological activity of micro and macroorganisms, and improves soil structure and fertility [20]. However, phytoremediation is a relatively slow process and may take several years to reduce the contaminant content in the soil to a safe and acceptable level due to small size and slow growth of most plants used for that purpose [16]. One avenue to circumvent this problem and accelerate decontamination is the use of fast-growing trees, such as willows and poplars [21-25]. Through their extensive and widespread root systems, which can measure up to several meters long, willows improve the structure and texture of soil [26] and reduce erosion [27]. Furthermore, willows have demonstrated an ability to adapt to varying soil textures (sandy to clay) and humidity, due to their high transpiration rate and their roots ability to tolerate seasonal floods. In addition to improving the landscape and providing habitat for wildlife, willows play a positive role in the restoration and accelerated revegetation of degraded areas (lands disturbed by industrial activities or left by agriculture) in temperate and boreal regions of the world due to their ability to remove contaminants [28]. After their harvest, they provide wood, fiber, biofuel and other forest products, due to their high biomass production. Some fast growing grasses and forbs are also used extensively in phytoremediation for similar purposes [29-31].

Phytoremediation is considered more effective for native microbial communities than human induced bioaugmentation. There are two types of factors that influence the effectiveness and survival of microbial strains introduced into the soil: (1) biotic factors (quick growth, easy to cultivate, tolerance to high concentrations of contaminants, competition between indigenous and exogenous microorganisms for carbon sources) and (2) abiotic factors (type and amount of contaminants, temperature, humidity, $\mathrm{pH}$, organic matter, aeration, soil type, chemical composition of the root exudates, etc.) [14,32-37]. Selection of microorganisms can be done either from sites with similar types of contaminants or by pre-adaptation in the laboratory. Indeed, bacteria can be isolated from contaminated soils, grown under certain conditions to obtain pure strains and then returned to the same soil: this is considered a re-inoculation with indigenous microorganisms [3,38,39]. In many cases, inoculation of a consortium of hydrocarbon-degrading bacteria is more effective than single strains, because the intermediate of a catabolic pathway for a strain can be degraded by other strains that have the suitable catabolic pathway [3,40-42].

In addition to providing mechanical support, water and nutrients, roots perform more specialized roles in the rhizosphere including the ability to synthesize and secrete a multitude of metabolites [43-45]. Plant roots release between $6 \%$ and $21 \%$ of photosynthetically fixed carbon $[43,46-48]$ in organic, amino and fatty acids, carbohydrates, vitamins, nucleotides, phenolic compounds, polysaccharides and proteins [49-51]. Microorganisms are attracted through chemotaxis [46,52] to these substrates and can use them for their metabolism. As a result, the rhizosphere is up to 100 times richer in microorganism biomass but poorer in diversity than bulk soil [53-56]: this is called "the rhizosphere effect" [57-59]. In addition to exudation of nutrients, vitamins, and minerals, the plant and its associated microbiome also produce and/or exude various secondary metabolites, many of which act as signals [44] or as compounds inhibitory to the growth and functioning of microorganisms or roots called allelochemicals [43,60-62]. For example, specific specific secondary products can initiate communication between microorganisms and conduct specialized interactions such as nodulation, pathogenesis, antibiotic production and DNA 
transfer between bacteria (conjugation) [63]. Many genes responsible for bacterial adaptation in soil and rhizosphere (e.g., degradation of organic compounds) are carried by conjugative plasmids [64]. In return, the ecological functions carried by the microbiota allow the plant to adapt to many types of environmental conditions and environmental changes [65].

\section{Actors of Phytoremediation: The Holobiont}

In phytoremediation, plants can absorb, concentrate, sequester, transform and eliminate contaminants (Figure 1) $[16,17,66]$. Even if plants can also produce several enzymes to degrade organic compounds (such as peroxidases and phenol oxidases), they are generally considered as a minor contributor to the dissipation of organic contaminants in soil [67]. Phytoremediation of hydrocarbons depends primarily on rhizoremediation (Figure 1) which involves the breakdown of contaminants in soil as a result of microbial activity at the roots [66,68,69]. Microorganisms can colonize three distinct areas of the root zone of a plant [46,63]: (1) the endosphere, i.e., all the cells inside the roots [70]; (2) the rhizoplane which is the root surface [63,71], usually as biofilm (i.e., multiple layers of mature microcolonies covered by mucus [63]); and (3) the rhizosphere, i.e., the soil immediately adjacent to roots (a few millimeters thick) and influenced by plant roots [72,73]. Rhizosphere is a complex ecosystem characterized by a large amount of microniches_-spatially close, but chemically heterogeneous - containing a high diversity of microorganisms [74]. The structure of the rhizosphere microbial community depends on soil type [75-78], temporal changes (seasons) and environmental factors $[79,80]$, plant species and genotype [75,81-85], plant development stage [85-87] and signaling of plant hormones [88].

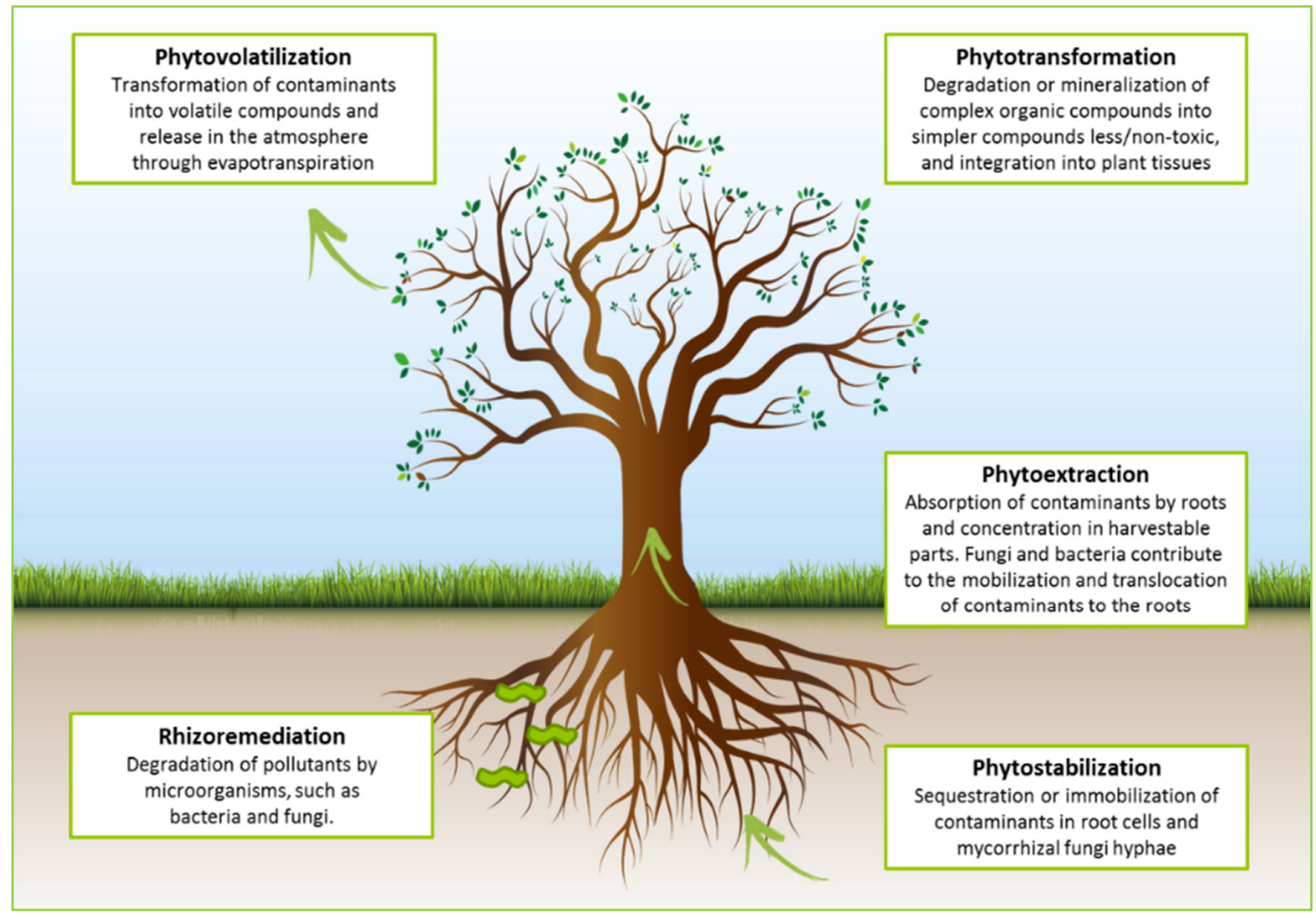

Figure 1. Mecanisms involved in phytoremediation $[16,17,66]$.

Plants and microorganisms have co-evolved to each take advantage of their association. Because of their sessile lifestyle, plants need to adjust to biotic and abiotic stresses present in their immediate environment [61]. Thus, a plant may promote the presence of certain microorganisms if they provide a selective advantage, in particular to act as a defense against certain pathogens [89] or enhance its growth and nutrition [90]. This symbiotic system is called "a holobiont". This notion extended the concept of an organism to all internal or surface microbial communities associated with it, i.e., the 
plant with its microbiota [91]. The microbial portion of the plant holobiont can be seen as a "facilitator component" that provides additional genes to the host and allows it to adjust to environmental conditions $[90,92]$. It is, therefore, considered that the unit of selection processes and adaptation is not the isolated individual but the whole "meta-organism", i.e., the species community; and the metabolites it produces is referred to as the metabolome [91,93]. This meta-organism results from the interaction of the host genome (plant) and its associated microbiome (including metabolites produced by both the plant and its associated microbiome), making a single dynamic entity: the hologenome, a target of natural selection [94,95]. Co-evolution shows that microorganisms present in a plant, whether parasite or symbiont, may have a considerable influence on their host. On one hand, the survival of the plant may be affected, through changes to many physiological functions, such as reproduction, development or immunity [91,96-102]. Disruptions of this association can then overturn acclimation capacity and thus the fitness of the species assemblage [91]. On the other hand, the interaction between heterogeneous communities with rapid (microbiota) and slow (macro-organisms) adaptability can bring out new selective traits and influence the species adaptability [91]. Indeed, under stressful environmental conditions, the symbiotic community can change quickly and this plasticity may play an important role both in the acclimatization and evolution of the plant [90]. In fact, phytoremediation results in a symbiotic interaction in the rhizosphere where plants and microorganisms act jointly in the degradation of organic contaminants $[66,68,69,103]$.

\section{Hydrocarbon Rhizoremediation}

Organic contaminants can provide microorganisms with a carbon source and electrons required in respiration [104]. Microorganisms are able to degrade simple hydrocarbons (linear and branched alkanes) to complex (aromatic compounds), with the exception of complex polyaromatic hydrocarbons (PAHs) that are not, in general, fully degraded [105]. Soil conditions were shown to be important for hydrocarbon degradation by microorganisms, and some authors proposed the following levels as optima: soil moisture at $30 \%$ of water holding capacity, soil $\mathrm{pH}$ between 6.5 and 8, oxygen content between $10 \%$ and $40 \%$, and low clay or silt content for soil type $[9,17]$. Even if hydrocarbon biodegradation has been reported in psychrophilic environments in temperate regions [106,107], the rate of biodegradation generally decreases with a decrease in temperature because it affects hydrocarbon solubility [108] and microbial activity [109]. Generally, the optimum temperature for hydrocarbon degradation in a soil environment is between 20 and $40{ }^{\circ} \mathrm{C}[54,110,111]$. Nutrients (nitrogen, phosphorus) have also been reported to be very important for hydrocarbon biodegradation [111-113]. The optimum nutrient content has been found to follow a C:N:P ratio of 100:10:1 [17,114]. However, excessive nutrient concentrations can also have negative effects, especially on aromatics, and inhibit hydrocarbon biodegradation [113,115-117].

Most individual species are not equipped with all the appropriate enzymes, so degradation is mainly achieved via a consortium of microorganisms with various enzyme systems [118-120]. Hydrocarbon-degrading microorganisms can be subdivided into two groups [17]: aerobic (in presence of oxygen) and anaerobic (in absence of oxygen). The fastest and most complete degradation of most organic pollutants is performed under aerobic conditions, due to the metabolic advantage of having the availability of $\mathrm{O}_{2}$ as an electron acceptor (Figure 2) [9,121].

Aerobic bacteria such as Pseudomonas, Alcaligenes, Sphingomonas, Rhodococcus and Mycobacterium have often been reported to degrade hydrocarbons, both alkanes and polyaromatic compounds [17]. Many of these bacteria use hydrocarbons as the only source of carbon and energy. The key step of aerobic degradation is the activation, i.e., the addition of one or two oxygen atoms to the hydrocarbon molecule (monooxygenases introduce one oxygen atom to a substrate while dioxygenases introduce two). For aliphatic hydrocarbons, the activation is catalyzed either by substrate-specific terminal oxygenases (monooxygenases, non-heme iron monooxygenases, dioxygenases) or subterminal oxidation (cytochrome P450) $[9,121,122]$. In aromatic hydrocarbons, four types of enzymes are involved: the Rieske non-heme iron oxygenases (RNHO), the flavoprotein monooxygenases (FPM), the soluble di-iron multicomponent monooxygenases (SDM) and the CoA ligases [123]. This activation makes the hydrocarbon more soluble 
in water, marks a reactive site, and introduces a reactive site for the next reactions [9,121]. In the case of aliphatic hydrocarbons, the activated molecule is then converted to an alkanol, then oxidized to the corresponding aldehyde, and converted into a fatty acid. Fatty acid is conjugated to CoA-which forms an acyl CoA-and processed by $\beta$-oxidation to generate acetyl-CoA [123]. Therefore, the final product of the oxidation of aliphatic hydrocarbons is acetyl-CoA, which is catabolised in the Krebs cycle, and fully oxidised to $\mathrm{CO}_{2}$ [121]. In the case of aromatic hydrocarbons, the activated molecule is not converted in alkanol, but in phenol intermediates (catechol or a structurally related compound) via peripheral pathways [121]. Phenol intermediates are further degraded by central pathways (intradiol or extradiol dioxygenases), resulting in di- or trihydroxylated aromatic compounds that can be introduced into the Krebs cycle, and fully degraded to $\mathrm{CO}_{2}$ [121,123]. Biosynthesis of cell biomass occurs from the central precursor metabolites, for example acetyl-CoA, succinate and pyruvate. Methylotrophs (methanogens) bacteria are also aerobic bacteria able to degrade hydrocarbons, using methane as source of carbon and energy [124,125]. In methanogenesis, the terminal process of biomass degradation, acetate and hydrogen are the most important immediate precursors. They are respectively converted into methane by acetoclastic and hydrogenotrophic methanogens [126]. Acetate can also be a precursor for methanogenesis through syntrophic acetate oxidation coupled to hydrogenotrophic methanogenesis, which is mediated by syntrophic bacteria and methanogenic archaea [126-129].

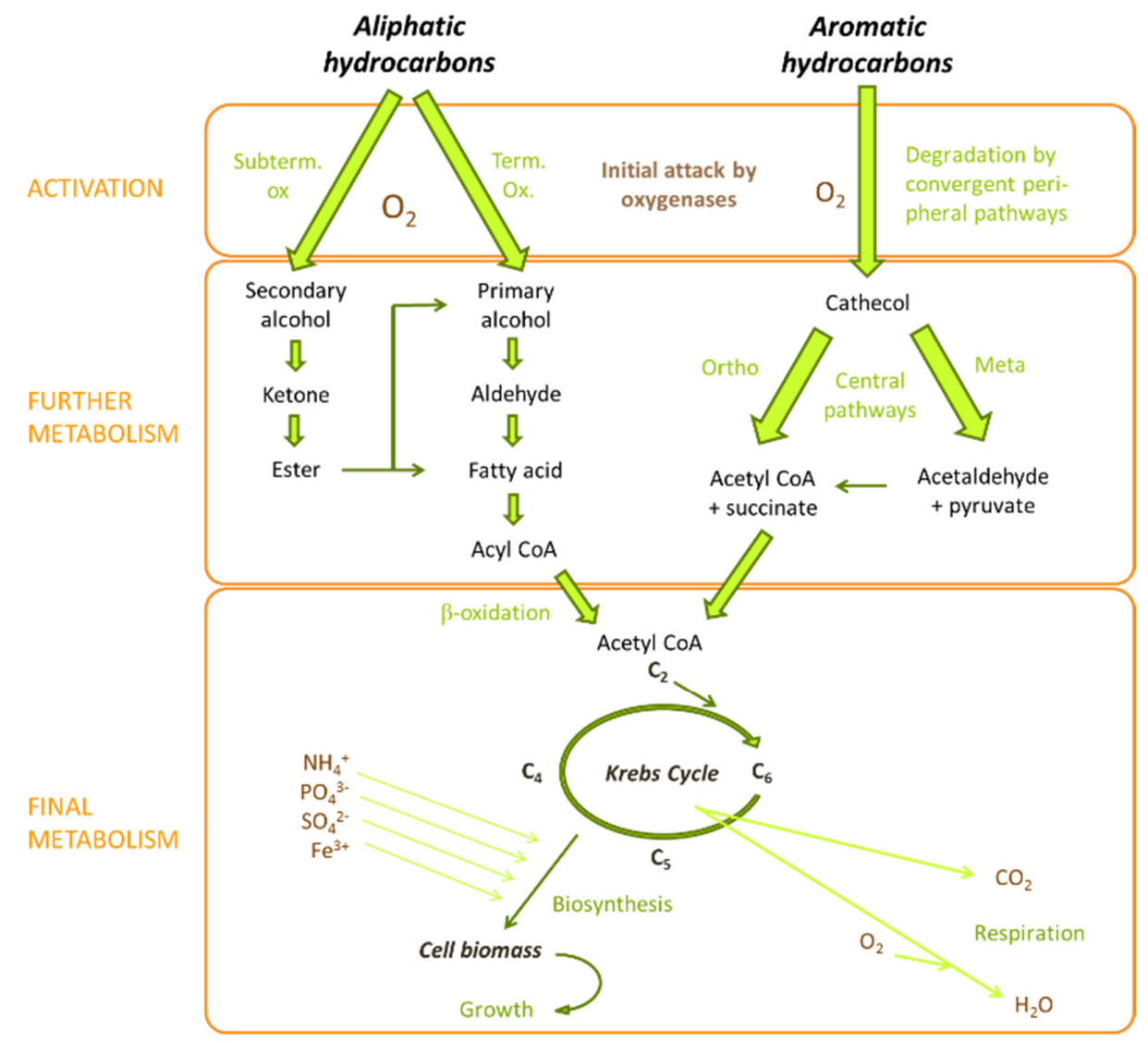

Figure 2. Degradation of aliphatic and aromatic hydrocarbons by aerobic bacteria. Subterm. ox.: subterminal oxidation; Term. ox.: terminal oxidation; Ortho: ortho cleavage pathway; Meta: meta cleavage patway; CoA: coenzyme A. [9,121,123,130-133].

Anaerobic bacteria are able to use different terminal electron acceptors to degrade hydrocarbons, such as sulfate (sulfate-reducing bacteria), nitrate, iron, manganese and, more recently found, chlorate [134]. These bacteria use a complete different pathway, based in reductive reactions to attack the aromatic ring: alkane activation at the subterminal carbon by the addition of fumarate, 
or carboxylation $[9,121,123]$. Anaerobic degradation has also been coupled to methanogenesis, fermentation and phototrophic metabolism but growth of these microorganisms and as a result, biodegradation rates are significantly lower compared to aerobic degraders. Despite not often being considered as aerobic bacteria, there is an increasing interest in the use of anaerobic bacteria for bioremediation $[17,135-138]$.

\section{Mechanisms of Root Exudation}

Rhizosphere microorganisms generally live under conditions of "nutrient starvation" and are thus constantly looking for nutrients. The most important nutrient sources excreted by roots are organic acids (citric, malic, succinic, oxalic and pyruvic), carbohydrates (glucose, xylose, fructose, maltose, sucrose, ribose), amino acids, fatty acids, proteins, enzymes, nucleotides and vitamins $[43,49,52,63,139]$. Microorganisms have developed sensory systems (chemotaxis) that guide them to these roots-secreted components in order to provide the necessary nutrition and energy for their survival and reproduction [140,141].

Root exudates can be grouped into two specific categories: low molecular weight compounds (LMWCs: amino and organic acids, sugars, phenolic compounds and other secondary metabolites) and high molecular weight compounds (HMWCs: polysaccharides and proteins) [43,49,142,143]. The quantity and quality of root exudates are determined by the cultivar, plant species, developmental stage, various environmental factors (soil type, $\mathrm{pH}$, temperature, nutrient availability) and the presence of microorganisms [49,144-149]. The greatest concentration of exudates occurs mostly at the root tips and at sites of lateral branching, decreasing with increasing distance from the root surface $[54,67,144,150]$. Gao et al. [67] proposed that decreases in concentrations of root exudates depend mainly on two aspects: diffusion and degradation due to chemical (sorption or desorption) [151,152] or biological process (e.g., microbial consumption). Microbial consumption contributes to the dissipation of root exudates because it provides the nutrition and energy necessary for survival and reproduction of rhizosphere microorganisms [140,141]. Diversity in root exudates generates different microbial communities that are specific to each plant species [46].

Plants use several mechanisms to export and secrete compounds in the rhizosphere $[45,49]$. Generally, root exudates are released either by passive (diffusion, ion channels and transport vesicles) or active mechanisms (secretion) $[43,45,46]$. The majority of organic low-molecular weight compounds (LMWC) are released through a passive transport (i.e., not requiring energy) which permits passage of an ion or a molecule across a membrane without energy intake $[46,143]$. Passive transport is opposed to active transport that requires energy.

Passive transport can be achieved through two means [153]. The first is a concentration gradient, spread by osmosis. Solutes diffuse through the cell membrane to reach an equilibrium concentration between the exterior and the interior of the molecule [153]. Non-polar molecules can pass through the membrane without making use of channels or transfer proteins due to their hydrophobic characteristics, this is simple diffusion [153]. Polar-molecules and ions can diffuse through the membrane due to a phenomenon called facilitated diffusion, using channels or permeases. The channels allow the passage of water and specific small ions such as $\mathrm{H}^{+}, \mathrm{Na}^{+}, \mathrm{K}^{+}$, and $\mathrm{Cl}^{-}$, which establish a pH gradient and membrane potential, maintain osmotic balance and stabilize cell volume $[153,154]$. Permeases can change their conformation upon binding with the molecule and upon its release. These proteins oscillate between two conformations, allowing them to spread the solute through the membrane. Small polar and uncharged molecules are transported by direct passive diffusion [155], a process that depends on membrane permeability [156], polarity of excreted compound and cytosolic $\mathrm{pH}$ [49]. Passive transport can also be mediated by an electrochemical gradient for charged molecules or ions. This gradient is influenced both by the concentration between intracellular and extracellular spaces and the electrical gradient of the membrane. Other compounds such as sugars, amino acids and caboxylates anions are transported across the membranes with the help of proteins, and their direction of movement is dependent on the electrochemical gradient that allows them to pass from the cytoplasm 
of root cells to the soil. There are specific transporters of sugars, amino acids and metals involved in the secretion of specific compounds by root cells [157-162]. Plants have metal homeostasis mechanisms to avoid excessive concentrations of free metal ions (e.g., $\mathrm{Fe}, \mathrm{Zn}, \mathrm{Mn}$ and $\mathrm{Cu}$ ). These mechanisms involve coordination of transport for assimilation, translocation and compartmentalization [163]. For example, grasses secrete mugineic acid, a ligand for metal secreted by the roots, and the complex $\mathrm{Fe}(\mathrm{III})$-AM reduce Fe toxicity and get it into root cells through a specific transporter YSL identified in maize [164,165]. However, passive transport with an electrochemical gradient cannot be done against the concentration gradient: it requires active transport and an energy intake.

Active transport refers to the passage of an ion or molecule through a membrane against its concentration gradient, and involves the hydrolysis of ATP. Plants have a sessile lifestyle and require many adaptive strategies to interact with the environment, suggesting that the number of compounds produced by plants may require a large number of transporters [166]. The excretion of compounds of high molecular weight by the roots usually involves transport vesicles $[45,167]$. Plant defense responses are accompanied by traffic of antimicrobial compounds at the site of infection by a pathogen. For example, pigmented-antimicrobial naphthoquinones are secreted in the apoplast of Boraginaceae roots (Lithospermum erythrorhizon) by a mechanism that has been observed in roots or root suspension cultures in response to a fungal elicitation (induction and enhancement of secondary metabolites to stimulate plant natural defenses) [61,168-170]. Although other unrelated studies have demonstrated transport via vesicles in plant leaves, there is no evidence that this mechanism exists in the roots, except for mucilage polysaccharides transported by Golgi through the root cap [171]. Root cells secrete secondary metabolites, polysaccharides and proteins, with the help of membrane transport proteins $[45,61]$. These transporters include ABC (ATP-binding cassette transporters) transporters [172-174], MATEs (multidrug and toxic compound extrusion) [168], MFS (major facilitator superfamily) [175], and ALMT (aluminum-activated malate transporter) [45]. Badri, Quintana et al. (2009) found that 25 genes of ABC transporters were significantly overexpressed in roots of Arabidopsis thaliana and played important roles in the process of secretion. In bacteria, $A B C$ transporters function as importers and exporters of compounds. In addition to the $\mathrm{ABC}$ transporters, MATEs are active transporters who export a wide range of substrates across membranes by using the electrochemical gradient of other ions [45]. Many MATE genes playing a role in the export of different compounds (such as alkaloids, antibiotic, anions citrate, phenolic compounds) have been identified and characterized in Arabidopsis [176-178], sorghum [179], barley [180], and rice [181]. ABC transporters and MATEs are involved in the transport of flavonoids to the vacuole [168].

\section{Root Exudation, the Ecological Driver of Microbial Communities in the Rhizosphere}

While plants produce and receive specific rhizosphere signals, they can also interfere with rhizosphere signals [60]. Root exudates are involved in determining the composition and diversity of the microbial community in the rhizosphere and can also play a significant role in the formation of the rhizosphere [43,51,60,172,182-187].

First, root exudates can alterate the microbial diversity. Micallef et al. [84] showed that each of eight different ecotypes of Arabidopsis released a unique suite of compounds into its rhizosphere, and that these exudation differences targeted different bacterial communities. Furthermore, a positive correlation has been demonstrated between phenolic compounds and a large number of unique OTUs (operational taxonomic units), compared to other exudates, such as sugars and amino acids [51]. For example, an Arabidopsis-mutant plant (containing ABC transporters that secrete more phenolic compounds to sugars compared to the wild type) caused significant changes in the microbial community [172]. Application of p-coumaric acid and vanillic acid, components of cucumber root exudates, increased the abundance and changed the composition of the rhizosphere bacterial community $[188,189]$. The abundances of Firmicutes, Betaproteobacteria and Gammaproteobacteria increased, indicating that these taxa may be involved in the degradation of p-coumaric acid. 
Secondly, roots can also alter the communication among bacteria, secreting compounds that mimic bacterial signals of quorum sensing [190]. Quorum sensing is described as the coordination of bacterial behaviors by regulation of gene expression in response to population densities of bacteria [60]. It is a form of communication between bacteria, mediated by autoinducers (small signal molecules) which are generally N-acyl homoserine lactones (AHLs) in Gram-negative and peptides in Gram-positive bacteria [44,60]. After reaching a high population density, an autoinducer activates transcription proteins that induce specific genes. Thus, intercellular signals allow a bacterial population to control expression of genes in response to cell density [44]. In plants, quorum sensing plays an important role in establishment of symbiotic, pathogenic or beneficial plant-microbe associations, and for regulating bacterial behaviors important for host infection (including motility, biofilm formation, plasmid transfer, nitrogen fixation, and synthesis of virulence factors, exopolysaccharides, and degradative enzymes) [60]. For example, pea (Pisum sativum) root exudates contain bioactive compounds that mimic AHLs signals that stimulate AHL-regulated behaviors in certain strains of bacteria and inhibit in others [191,192]. Similarly, compounds mimicking the activity of AHLs and affecting bacterial behaviors regulated by quorum sensing are present in Coronilla varia (crownvetch), Medicago truncatula (barrel medic, at least 15 compounds) [190], Oryza sativa (rice), Glycine max (soybean) and Lycopersicon lycopersicum (tomato) $[191,193,194]$. Moreover, strigolactones produced by Physcomitrella patens (moss) act as signaling factors that control the developmental process and the production of pseudo-quorum sensing signals [195].

Thirdly, root exudates can mediate rhizospheric interactions (plant-microbe and microbe-microbe) by recruiting beneficial specific microorganisms such as PGPR (plant growth promoting rhizobacteria), mycorrhizal fungi or nitrogen-fixing bacteria [46,60,81,89,196-201]. The release of exudates, such as sugars and amino acids, was shown to attract PGPR [46,97]. Pseudomonas possesses chemotactic proteins for malic acid, citric acid, and amino acids (especially leucine) that help colonization of tomato roots [202,203]. Likewise, Rudrappa et al. [204] demonstrated that released-malic acid allows the recruitment of Bacillus subtilis (PGPR). Some cell surface glycoproteins called arabino galactan proteins are secreted by the root cap of Arabidopsis, and also play an important role in the recognition and attachment of rhizobia on the root surface [205]. Regarding the phenolic compounds, these can act as specific substrates and signaling molecules, while at the same time playing multifunctional roles in rhizospheric plant-microbe interactions, such as legume-rhizobia symbioses [51,206-210]. Indeed, legume plants can secrete phenolic compounds to attract and induce the chemotaxis of Rhizobium species, which have the ability to use phenolic acids as a carbon source [211,212], and can also initiate symbiosis between them [213]. Weston and Mathesius [214,215] described production, transport and roles in the rhizosphere of two phenolic compounds: (1) flavonoids (low molecular weight compounds), generally described as non-essential for plant survival, unlike primary metabolites; and (2) long chain hydroquinones or phenolic lipids (including sorgoleones), released by passive exudation from Sorghum spp. [216]. Some of the more well-known biological roles of flavonoids in the rhizosphere include [60,214,215]: (1) chemo-attraction that lead rhizobia to the root surface [217] (2) induction of the expression of nod genes, which encode enzymes for the synthesis of Nod factors or lipochitine oligosaccharides (LCOs) $[207,210]$ (3) activation of nodule formation in which bacteria fix atmospheric nitrogen for plants $[63,218]$ (4) increasing of the efficiency of indol-3-acetic acid production by Rhizobium species and regulate nodule morphogenesis [213]. The auxin phytohormone indol-3-acetic acid can also be produced by bacteria and is suspected to act as a signaling molecule that can affect their gene expression [219]. Similarly, phenolic acids involved nodule morphogenesis and in rhizobial defense have been detected in roots and root nodules of Arachis hypogaea [220].

Plants can also use exudates to defend themselves against pathogens [217]. Proteins secreted by roots are important for recognition of pathogenic and non-pathogenic bacteria [221,222]. For example, lectins function as defense factors and recognition in symbiotic interactions [223]. During the flowering period of Arabidopsis thaliana, roots excrete more protein involved in defense, such as chitinases, glucanases and myrosinases [224]. Furthermore, protein patterns released as root exudates depend 
on the identity of microorganisms exposed to the roots of $A$. thaliana [222]. Pseudomonas syringae, an A. thaliana pathogen, highly induced secretion (from $A$. thaliana) of defense proteins, such as peroxidases, glycosyl hydrolase family 17 , chitinase, and glycosyl hydrolase family 18 [222].

In return, the quality and quantity of exudates is highly influenced by the presence of microorganisms. For example, Matilla, et al. [138] found that $A$. thaliana produce distinct patterns of root exudation when it grows with and without Pseudomonas putida KT2440. In addition, when the biocontrol strain Pseudomonas WCS365 is added in sufficient quantity for the biocontrol to operate, organic acids (citric acid especially) is strongly increased, while the amount of succinic acid drastically decreased [225]. Similarly, mycorrhizal colonization was shown to modify the exudates of tomato roots [52], and the stimulatory effect of root exudates from many plant species to the germination of conidia of Fusarium oxysporum f. sp. lycopersici, a tomato root pathogen [226].

\section{Impact of Root Exudates on Hydrocarbon Degradation}

Root exudation is now considered to be the most important factor in the mediation of hydrocarbon biodegradation in the rhizosphere [54,67,104,141,227-232]. Root exudates serve as a carbon source and energy for microorganisms, and also improve the hydrocarbon degradation in the rhizosphere by stimulating hydrocarbon-degrader populations [67].

In contaminated soil, the contaminant distribution gradient is negatively correlated with the gradient of root exudates, with the lowest hydrocarbon concentration and the highest exudate concentration close to the roots $[67,233]$. Corgie et al. [68] reported that phenanthrene biodegradation reached $86 \%$ in the first $3 \mathrm{~mm}$ from the roots, $48 \%$ between 3 and $6 \mathrm{~mm}$, and $36 \%$ between 6 and $9 \mathrm{~mm}$. They observed a parallel bacterial gradient, where high numbers of heterotrophs and PAH-degrading bacteria were close to the roots. Similarly, in the rhizosphere of perennial ryegrass (Lolium perenne L.) growing in a petroleum hydrocarbon contaminated soil, the highest rates of hydrocarbon degradation and the microbial degraders were mainly found within $3 \mathrm{~mm}$ of the root surface [234]. In a phenanthrene-contaminated soil, Cébron et al. [235] observed that major phenanthrene degraders were Pseudoxanthomonas spp. (Gammaproteobacteria) and Microbacterium spp. (Actinobacteria). But when root exudates of ryegrass were added, the population of phenanthrene degraders shifted towards mostly the Actinobacterium Arthrobacter spp., the Gammaproteobacteria Pseudomonas stutzeri and Pseudoxanthomonas mexicana. Interestingly, the Firmicutes Bacillus spp., Paenibacillus spp. and Pseudomonas spp. were also found to be able to use both root exudates and phenanthrene as carbon source [182]. Arthrobacter spp. was shown to degrade hydrocarbons and more specifically phenanthrene [236,237]. Kozdrój and van Elsas [238] also found Pseudomonas and Arthrobacter as dominant active phenanthrene degraders either in the presence of artificial root exudates or with phenanthrene alone.

Plant roots may enhance microbial biodegradation of petroleum hydrocarbons via physical processes such as nutrient and pollutant transport, microbial attachment sites and soil aeration (Figure 3) [54]. The first and most significant role of root exudates in the improvement of petroleum hydrocarbon degradation is that they provide microorganisms with a source of energy and nutrients, which supports their growth and activity [239,240] (Figure 3A). The forms of carbon and nitrogen exuded by roots, i.e., high molecular weight organic polymers, are complex and mostly insoluble [54]. Therefore, they may have relatively long biodegradation times [80,241]. Increasing the microbial biomass and activity by exudation of labile $\mathrm{C}$ and $\mathrm{N}$ can be a solution. For example, the addition of root debris to phenanthrene contaminated soils only improve phenanthrene degradation after 20 days, in contrast to more labile water soluble exudates, which reflects the low biodegradability of the root debris [231]. In contrast, the high solubility of low molecular weight exudates allows them a higher mobility in soil and a rapid uptake by microbial cells [54]. Carbohydrates, amino acids and organic acid represent the largest proportion of low molecular weight root exudates, and are fundamental to the provision of easily degradable energy and nutrient sources to the rhizosphere [242]. For example, the addition of low molecular weight root exudates can generate a rapid response (within $1 \mathrm{~h}$ ) in the microbial respiration. However, several days may be required to observe changes in gene 
expression and microbial biomass [243,244]. Furthermore, root secreted compounds involved in plant nutrient acquisition, such as enzymes (e.g., acid phosphatases), protons and chelating agents (e.g., organic acid anions and other phytosiderophores), also provide a source of nutrients to rhizosphere microorganisms [150,245-247].

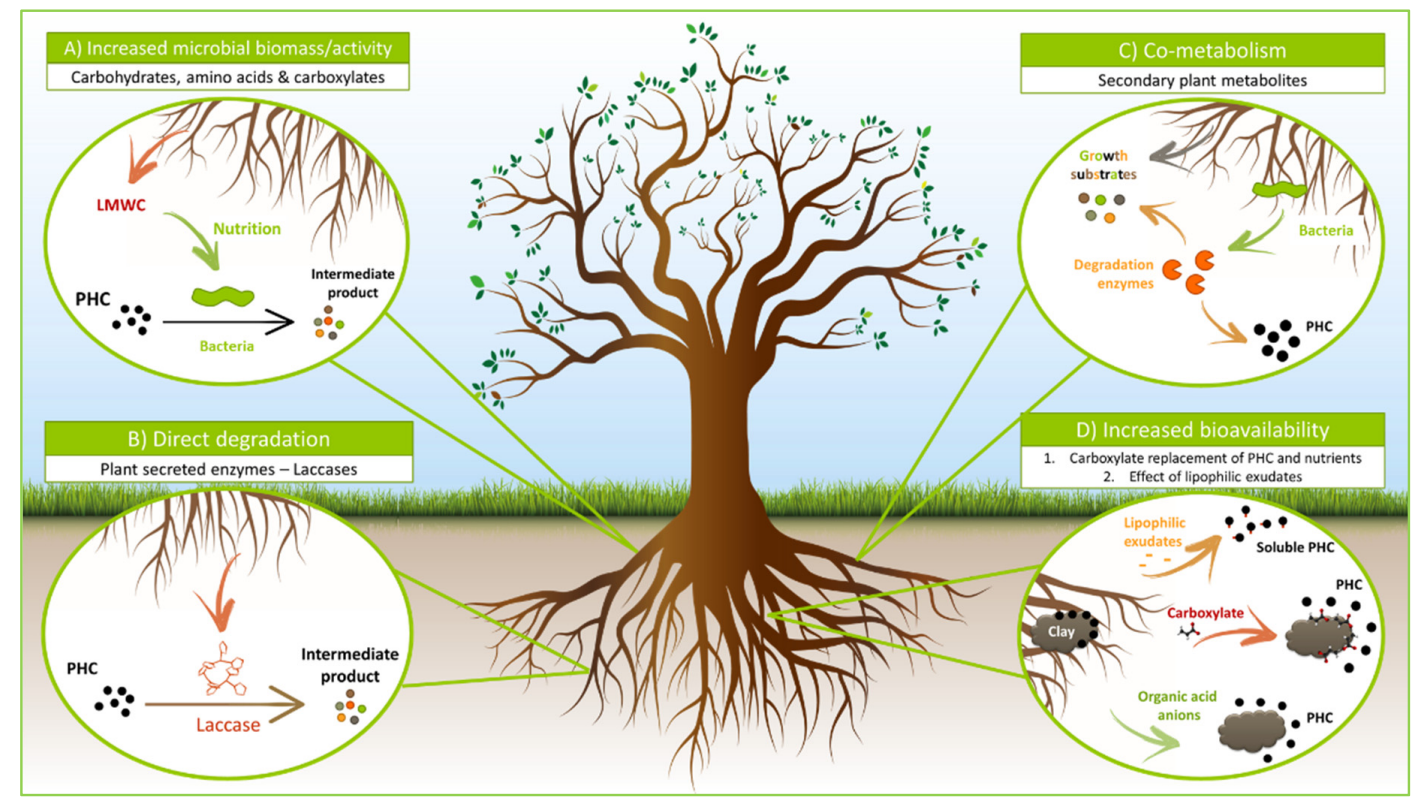

Figure 3. Improvement of petroleum hydrocarbon degradation by root exudates. PHC: Petroleum hydrocarbon; LMWC: Low molecular weight compounds. Adapted from Martin et al. [54].

Secondly, plants may directly improve degradation via the root exudation of enzymes, such as laccases, phenol oxidases and peroxidases which catalyze the oxidation of various hydrocarbons and degrade them into intermediate products (Figure 3B) [54,67]. However, microbially derived enzymatic breakdown is considered to be the primary pathway for petroleum hydrocarbons degradation [54].

Thirdly, many secondary plant metabolites exuded by roots, such as flavonoids, are structurally similar to aromatic hydrocarbons (Figure 3C) [248,249]. Therefore, structural analogy improve hydrocarbon degradation by stimulating co-metabolic processes, which involves the oxidation/mineralization of petroleum hydrocarbons molecules that do not supporting growth (for example benzo- $a$-pyrene [250]) in the presence of other growth supporting root exudates [251,252]. Co-metabolism seems to be the primary process underlying degradation of recalcitrant hydrocarbons [240,253].

Finally, bioavailability is often a limiting factor for hydrocarbon degradation because polycyclic aromatic hydrocarbons are easily adsorbed by soil solids, such as soil organic matter, after entering the soil (Figure 3D) [67]. Root exudates can increase the solubility of hydrocarbons and alter their bioavailability [54,254,255], making them more available for a future microbial attacks [256,257]. Root exudates collected from plant roots [230,231,258] or artificial root exudate mixtures [229] can be amended to contaminated soils to enhance desorption and promote the success of rhizoremediation. For example, Gao et al. [255] used artificial root exudates as amendments, and observed a considerable increase of desorption of phenanthrene and pyrene from soils. Similarly, LeFevre et al. [259] showed that root exudates, both artificial and harvested from plants, enhanced naphthalene desorption from soils, providing an abiotic contribution to the "rhizosphere effect" for degradation of naphthalene. As exudate amendments, low-molecular-weight organic acids (LMOAs) can influence desorption of hydrophobic organic contaminants from soil and hence alter their bioavailability [7,260-262]. White et al. [263] showed that bioavailability of dichlorodiphenyldichloroethylene (DDE) in soils is increased in the presence of LMOAs, such as succinic, tartaric, malic, malonic, oxalic, citric and 
ethylenediaminetetraacetic acid (EDTA). Similarly, Zhao et al. [264] observed an enhanced release of hexachlorocyclohexane from soils in the presence of oxalic, tartaric and citric acid.

Yang et al. [69] and Ling et al. [7,265] found that LMWOAs (such as citric and oxalic acids) significantly enhanced the desorption availability of hydrocarbons from a contaminated soil, and continued to desorb more PAHs from soil during multiple desorption cycles. In fact, the mechanism by which LMWOAs promote desorption of PAHs from soil was proposed to begin by a disruption of soil organic matter (SOM)-metal cation-mineral linkages in soils, thus releasing SOM and simultaneously increasing dissolved organic carbon in the surrounding solution which causes the enhanced PAH desorption from soil [7]. All these results suggest that the amendment of contaminated soils with LMWOAs can promote PAH desorption from soils, which might be used as a new approach to enhance bioavailability—and therefore bioremediation—of hydrophobic organic compounds in soils [7]. Organic acid anions exuded by roots may also enhance the desorption of hydrocarbons and/or compete for soil adsorption sites from the soil matrix, such as clay surfaces $[6,255,266]$. Moreover, some microorganisms are able to release biosurfactants, such as rhamnolipids, that can increase the solubility of certain organic contaminants and improve the ability of microbial cells to attach to oil droplets [267-269].

\section{Lateral Gene Transfer in Rhizosphere and Hydrocarbon Degradation}

The evolution of bacteria is accelerated by their ability to acquire genes directly from other organisms [270]. The acquired amount of genes in a prokaryotic genome has been found to vary between $66 \%$ and $96 \%$ [271]. Horizontal acquisition of catabolic genes allows microbial populations that have different physiological properties, cellular structures or ecological niches, to acquire new capabilities to improve their performance in their current ecological niche (such as using root exudates for growth) or to invade a new niche [270,272]. Lateral gene transfer is a major driver of bacterial evolution and adaptability [273], and is driven by three mechanisms: the transformation (acquisition of foreign naked DNA), transduction (bacteriophage-mediated gene transfer) and conjugation (plasmids and integrative conjugative elements-ICEs) [274]. Of the three mechanisms of lateral gene transfer, conjugation is one of the most important for exchanging genes $[275,276]$. Plasmids are autoreplicatives extrachromosomal molecules of DNA, mostly circular but otherwise linear [277], and are transmitted both vertically (from mother cell to daughter during bacterial division) and horizontally (from a donor cell to a recipient cell). Plasmids are mosaic genomes that include two distinct regions [278]: (1) skeleton genes, often conserved among members of the same family of plasmids, ensure replication and maintenance of the plasmid in the cell and transfer [279]; and (2) accessory genes encoding functions that are frequently beneficial to the host cell. These functions benefit the host cell in many different ways, e.g., degrading environmental pollutants and using them as a carbon or nitrogen source, or providing virulence [280], resistance to an antibiotic [281] or a metal or metalloid trace element, and other catabolic functions [282].

Root exudation has been to have an effect on conjugation. A large number of environmental "hot spots" where lateral gene transfer is high were identified [283], including the rhizosphere of plants [284]. Lateral gene transfer is known to occur with high frequency in the rhizosphere [285-287], and to be stimulated in part by an increased root exudation [283]. The high rates of lateral gene transfer in the rhizosphere, compared to bulk soil, were attributed to the high cell density, distribution, and accessibility to root exudates that stimulate bacterial activity, exudation and root growth $[287,288]$.

Molbak et al. [283] studied lateral gene transfer in the rhizospheres of pea and barley. They discovered that there was 17 times more lateral gene transfer in pea rhizosphere than in barley $\left(3.5 \pm 0.7 \times 10^{-3}\right.$ trans-conjugants per donor for peas and $2 \pm 0.5 \times 10^{-4}$ for barley). They proposed that in the pea rhizosphere, dense and uniform colonization of donor cells along the whole length of the root resulted in a higher encounter frequency between donor and recipient cells, and therefore a larger transfer rate. The spread into pea roots deeper in the soil is suspected to be due to passive transport or motility. In barley rhizosphere, populations are present mainly in the spermosphere and 
in the root portion closer to the surface of the soil, so few encounters between donor and recipient cells take place. Schwaner and Kroer [289] observed similar results using different bacterial strains, plasmids and inoculation techniques which confirmed species-specific differences in the frequency of rhizospheric lateral gene transfer. Differences in bacterial activity have also been suggested as an important determinant of the transfer [289].

Many bacterial genes involved in PAH degradation are carried on conjugative plasmids [290]. Phillips et al. [228] studied two catabolic genes involved in hydrocarbon degradation commonly carried by conjugative plasmids: C2,3O (catechol 2,3 dioxygenase) and nahAc (naphthalene dioxygenase (NDO) iron sulfur protein). On one hand, $\mathrm{C} 2,3 \mathrm{O}$ is an enzyme encoding an archetypal pathway for the catabolism of monocyclic aromatics to aliphatic metabolites [291]. It is more specifically involved in the degradation of xylene, catalyzing the oxidative cleavage of catechols (i.e., incorporate dioxygen into the substrate catechol) to form a 2-hydroxymuconate semialdehyde [291]. C2,3O is carried by the TOL plasmid of Pseudomonas putida mt-2 (ATCC 23973) and the bacterium degrades $m$-xylene to $\mathrm{CO}_{2}$, acetate, acetaldehyde, and pyruvate. On the other hand, biodegradation pathways of aromatic hydrocarbon by bacteria are initiated by aromatic hydrocarbon dioxygenases [292]. The three-component naphthalene dioxygenase enzyme system catalyzes the first step in the aerobic degradation of naphthalene by Pseudomonas sp. strain NCIB 9816-4 [293,294]: naphthalene + NADH $+\mathrm{H}^{+}+\mathrm{O}_{2} \leftrightarrow(1 \mathrm{R}, 2 \mathrm{~S})-1,2-$ dihydronaphthalene-1,2-diol $+\mathrm{NAD}^{+}$[292]. C2,3O and nahAc genes are commonly found on the same plasmid [228] with C2,3O often present in multiple copies [295,296]. Phillips et al. [228] observed a positive correlation between the copy numbers of the two genes and the PAH-mineralization rate, suggesting that plasmid transfer may have been a significant factor influencing the changes in degradation potential. The authors also observed that nahAc and C2,3O copy numbers are significantly impacted by exudate composition, with specific compounds associated with either increased (acetate, alanine) or decreased (malonate) degradative capacity. Organic acid acetate and the amino acid alanine have already been shown to directly increase HGT events [297].

\section{Conclusions and Perspectives}

Rhizoremediation can provide a cost effective and environmentally sustainable remediation alternative for the breakdown of hydrocarbon contaminants from the soil [54]. In this review, we clearly identified root exudates as a key ecological driver in the rhizosphere. Although numerous studies speculated that root exudation of organic compounds is the driving factor behind hydrocarbon rhizoremediation $[54,67,104,141,227-232]$, the extent to which biodegradation is achieved is highly variable amongst plant species [54]. Furthermore, studies directly linking the composition and quantity of root exudates to hydrocarbon biodegradation are scarce [54]. Carboxylates (LMWOA) are a significant component of the root exudate mixture and are thought to improve hydrocarbon biodegradation by promoting microbial activity through the provisioning of an energy source, increasing phosphorus supply and/or enhancing the bioavailability of the contaminant [54]. However, the impact of carboxylates on the soil microbial community has received considerably little attention and their influence on rhizoremediation of petroleum hydrocarbons so far lacks experimental study.

In contrast, over the past ten years many studies have demonstrated the beneficial impacts of biostimulation (amendment) with root exudates on hydrocarbon degradation [7,69,230,231,255,258,259,263-265,298,299]. Furthermore, root exudates stimulate lateral gene transfer in the rhizosphere [283,289], including hydrocarbon degrading genes [228]. However, the evolution of indigenous microorganisms - which implies mutational events and horizontal gene transfer-and the development of their hydrocarbon-degrading abilities are relatively slow processes [3]. The improvement of the biodegrading potential of microbial communities can be resolved by promoting horizontal gene transfer between modified organisms and wild strains, allowing them to acquire new degradation functions. For example, hydrocarbon-degrading genes carried by plasmids in one or more donor strains can be transferred to a recipient indigenous microflora, i.e., bioaugmentation of contaminated soil with genetic modified microorganisms. Weyens et al. [300] studied lateral transfer 
of toluene-degrading genes between the donor strain Burkholderia vietnamiensis BU61 (equipped with plasmid TOM-TEC coding for degradation of toluene and trichlorethylene (TCE)) and two recipient strains, Burkholderia sp. HU 001 (rhizosphere) and Pseudomonas sp. HU 002 (endophyte). Conjugation produced rhizospheric and endophytic strains able to degrade toluene, which were inoculated in willow rhizosphere. Inoculation with this consortium of plant-associated bacteria equipped with the appropriate characteristics resulted in an improved phytoremediation of a toluene contaminated site: the degradation of toluene was improved leading to decreased toxicity and evapotranspiration for willows. Filonov et al. [301] constructed a Pseudomonas putida strain (KT 2442), with naphtalene-degrading genes carried by pNF142 plasmid. Twelve days after the bioaugmentation of a naphtalene-contaminated soil, the naphthalene concentration decreased from 2 to $0.2 \mathrm{mg} / \mathrm{g}$ of soil and pNF142 plasmid has been transferred to indigenous bacteria. The inoculated strain remained stable and competitive for 40 days. More recently, Wang et al. [302] inoculated Pseudomonas fluorescens TP13 strains, which contained C23O (catechol 2,3-dioxygenase) genes carried by TOL plasmids, into the soil of a tomato farmland contaminated with hydroxybenze. Strain TP13 was able to colonize the tomato rhizosphere. The number of rhizosphere bacteria containing TOL plasmids with $\mathrm{C} 23 \mathrm{O}$ gene increased gradually in the later stages of the experiment, and was strongly negatively correlated with phenol content. Furthermore, six strains of rhizosphere bacteria isolated were found to possess large plasmids containing identical C23O genes almost identical to those of strain TP13. Wang et al. [302] confirmed that plasmids were transferred from strain TP13 to rhizosphere bacteria, and that horizontal gene transfer stimulated hydroxybenzene degradation and plant growth in the contaminated farmland after 20 days.

It would be interesting to combine biostimulation with root exudates and bioaugmentation of hydrocarbon degrading genes carried by plasmids to improve hydrocarbon degradation, i.e., creating a microorganism that is able to degrade hydrocarbon and transfer its degradation capacities to others (with degradation genes carried by plasmid) and inoculating them in soil with root exudates amendments. At this time, to our knowledge, no experiment on this scale has yet been conducted.

Acknowledgments: We acknowledge funding for this work by the GenoRem Project, which was primarily financed by Genome Canada and Genome Quebec. This project was also supported by an NSERC grant provided to M. St-Arnaud. We would like to also aknowledge Katrina Dingle Abram for the English spelling and grammar revision as well as the reviewers and editors for their judicious comments.

Author Contributions: Literature review: F.R. Writing: F.R., M.S.A. Figures design: F.R. Critical revision: M.S.A. Final approval: M.S.A.

Conflicts of Interest: The authors declare no conflict of interest.

\section{References}

1. Kvenvolden, K.A.; Cooper, C.K. Natural seepage of crude oil into the marine environment. Geo-Mar. Lett. 2003, 23, 140-146. [CrossRef]

2. Committee on Oil in the Sea. Oil in the Sea III: Inputs, Fates and Effects; National Academies Press: Washington, DC, USA, 2003.

3. Mrozik, A.; Piotrowska-Seget, Z. Bioaugmentation as a strategy for cleaning up of soils contaminated with aromatic compounds. Microbiol. Res. 2010, 165, 363-375. [CrossRef] [PubMed]

4. Nadal, M.; Schuhmacher, M.; Domingo, J.L. Levels of pahs in soil and vegetation samples from tarragona county, Spain. Environ. Pollut. 2004, 132, 1-11. [CrossRef] [PubMed]

5. Wehrer, M.; Totsche, K.U. Pah release from tar-oil contaminated soil material in response to forced environmental gradients: Implications for contaminant transport. Eur. J. Soil Sci. 2008, 59, 50-60. [CrossRef]

6. An, C.J.; Huang, G.H.; Wei, J.; Yu, H. Effect of short-chain organic acids on the enhanced desorption of phenanthrene by rhamnolipid biosurfactant in soil-water environment. Water Res. 2011, 45, 5501-5510. [CrossRef] [PubMed]

7. Ling, W.; Sun, R.; Gao, X.; Xu, R.; Li, H. Low-molecular-weight organic acids enhance desorption of polycyclic aromatic hydrocarbons from soil. Eur. J. Soil Sci. 2015, 66, 339-347. [CrossRef]

8. De Sousa, C.A. Urban brownfields redevelopment in Canada: The role of local government. Can. Geogr. 2006, 50, 392-407. [CrossRef] 
9. Das, N.; Chandran, P. Microbial degradation of detroleum hydrocarbon contaminants: An overview. Biotechnol. Res. Int. 2011, 2011. [CrossRef] [PubMed]

10. Environmental Protection Agency. Introduction to Phytoremediation; EPA/600/R-99/107; Environmental Protection Agency: Washington, DC, USA, 2000.

11. Glass, D.J. The 1998 United States Market for Phytoremediation; D. Glass Associates: Needham, MA, USA, 1998; p. 140.

12. Van Epps, A. Phytoremediation of Petroleum Hydrocarbons; Environmental Protection Agency: Washington, DC, USA, 2006.

13. Drake, E.N. Phytoremediation of aged petroleum hydrocarbons in soil. In Proceedings of the IBC Phytoremediation Conference, Seattle, WA, USA, 18-19 June 1997.

14. Pilon-Smits, E. Phytoremediation. Annu. Rev. Plant Biol. 2005, 56, 15-39. [CrossRef] [PubMed]

15. Hassan, S.; St-Arnaud, M.; Labreque, M.; Hijri, M. Phytoremediation: Biotechnological procedures involving plants and arbuscular mycorrhizal fungi. In Mycorrhizal Biotechnology; Devarajan Thangadurai, C.A.B., Hijri, M., Eds.; CRC Press: New York, NY, USA, 2010; p. 152.

16. Khan, A.G. Role of soil microbes in the rhizospheres of plants growing on trace metal contaminated soils in phytoremediation. J. Trace Elem. Med. Biol. 2005, 18, 355-364. [CrossRef] [PubMed]

17. Vidali, M. Bioremediation. An overview. Pure Appl. Chem. 2001, 73, 1163-1172. [CrossRef]

18. Miller, R. Phytoremediation: Technology Overview Report; Ground Water Remediation Technologies Analysis Center: Pittsburgh, PA, USA, 1996; Volume 39, p. 80.

19. Wenzel, W.W.; Adriano, D.C.; Salt, D.; Smith, R. Phytoremediation: A plant-microbe-based remediation system. Bioremediat. Contam. Soils 1999, 37, 457-508.

20. Salt, D.E.; Smith, R.D.; Raskin, I. Phytoremediation. Annu. Rev. Plant Physiol. Plant Mol. Biol. 1998, 49, 643-668. [CrossRef] [PubMed]

21. Bissonnette, L.; St-Arnaud, M.; Labrecque, M. Phytoextraction of heavy metals by two salicaceae clones in symbiosis with arbuscular mycorrhizal fungi during the second year of a field trial. Plant Soil 2010, 332, 55-67. [CrossRef]

22. Desjardins, D.; Pitre, F.; Guidi Nissim, W.; Labrecque, M. Differential uptake of silver, copper and zinc suggests complementary species-specific phytoextraction potential. Int. J. Phytorem. 2015. [CrossRef] [PubMed]

23. Guidi, W.; Kadri, H.; Labrecque, M. Establishment techniques to using willow for phytoremediation on a former oil refinery in southern Quebec: Achievements and constraints. Chem. Ecol. 2012, 28, 49-64. [CrossRef]

24. Labrecque, M.; Teodorescu, T.I. Field performance and biomass production of 12 willow and poplar clones in short-rotation coppice in southern Quebec (Canada). Biomass Bioenergy 2005, 29, 1-9. [CrossRef]

25. Tesar, M.; Reichenauer, T.G.; Sessitsch, A. Bacterial rhizosphere populations of black poplar and herbal plants to be used for phytoremediation of diesel fuel. Soil Biol. Biochem. 2002, 34, 1883-1892. [CrossRef]

26. Abrahamson, L.; Robison, D.; Volk, T.; White, E.; Neuhauser, E.; Benjamin, W.; Peterson, J. Sustainability and environmental issues associated with willow bioenergy development in New York (USA). Biomass Bioenergy 1998, 15, 17-22. [CrossRef]

27. Kenney, W.; Sennerby-Forsse, L.; Layton, P. A review of biomass quality research relevant to the use of poplar and willow for energy conversion. Biomass 1990, 21, 163-188. [CrossRef]

28. Kuzovkina, Y.A.; Quigley, M.F. Willows beyond wetlands: Uses of salix 1. Species for environmental projects. Water Air Soil Pollut. 2005, 162, 183-204. [CrossRef]

29. Merkl, N.; Schultze-Kraft, R.; Infante, C. Assessment of tropical grasses and legumes for phytoremediation of petroleum-contaminated soils. Water Air Soil Pollut. 2005, 165, 195-209. [CrossRef]

30. Olson, P.E.; Flechter, J.S.; Philp, P.R. Natural attenuation/phytoremediation in the vadose zone of a former industrial sludge basin. Environ. Sci. Pollut. Res. 2001, 8, 243-249. [CrossRef]

31. Olson, P.E.; Fletcher, J.S. Ecological recovery of vegetation at a former industrial sludge basin and its implications to phytoremediation. Environ. Sci. Pollut. Res. 2000, 7, 195-204. [CrossRef] [PubMed]

32. Atlas, R.M.; Cerniglia, C.E. Bioremediation of petroleum pollutants-Diversity and environmental aspects of hydrocarbon biodegradation. Bioscience 1995, 45, 332-338. [CrossRef] 
33. Karamalidis, A.K.; Evangelou, A.C.; Karabika, E.; Koukkou, A.I.; Drainas, C.; Voudrias, E.A. Laboratory scale bioremediation of petroleum-contaminated soil by indigenous microorganisms and added pseudomonas aeruginosa strain spet. Bioresour. Technol. 2010, 101, 6545-6552. [CrossRef] [PubMed]

34. Tyagi, M.; da Fonseca, M.M.R.; de Carvalho, C.C.C.R. Bioaugmentation and biostimulation strategies to improve the effectiveness of bioremediation processes. Biodegradation 2011, 22, 231-241. [CrossRef] [PubMed]

35. Cho, Y.-G.; Rhee, S.-K.; Lee, S.-T. Effect of soil moisture on bioremediation of chlorophenol-contaminated soil. Biotechnol. Lett. 2000, 22, 915-919. [CrossRef]

36. Bento, F.M.; Camargo, F.A.; Okeke, B.C.; Frankenberger, W.T. Comparative bioremediation of soils contaminated with diesel oil by natural attenuation, biostimulation and bioaugmentation. Bioresour. Technol. 2005, 96, 1049-1055. [CrossRef] [PubMed]

37. Wolski, E.A.; Murialdo, S.E.; Gonzalez, J.F. Effect of $\mathrm{pH}$ and inoculum size on pentachlorophenol degradation by pseudomonas sp. Water SA 2007, 32, 93-98. [CrossRef]

38. Dong, X.; Hong, Q.; He, L.; Jiang, X.; Li, S. Characterization of phenol-degrading bacterial strains isolated from natural soil. Int. Biodeterior. Biodegrad. 2008, 62, 257-262. [CrossRef]

39. Cordova-Rosa, S.; Dams, R.; Cordova-Rosa, E.; Radetski, M.; Corrêa, A.; Radetski, C. Remediation of phenol-contaminated soil by a bacterial consortium and acinetobacter calcoaceticus isolated from an industrial wastewater treatment plant. J. Hazard. Mater. 2009, 164, 61-66. [CrossRef] [PubMed]

40. Heinaru, E.; Merimaa, M.; Viggor, S.; Lehiste, M.; Leito, I.; Truu, J.; Heinaru, A. Biodegradation efficiency of functionally important populations selected for bioaugmentation in phenol-and oil-polluted area. FEMS Microbiol. Ecol. 2005, 51, 363-373. [CrossRef] [PubMed]

41. Ghazali, F.M.; Rahman, R.N.Z.A.; Salleh, A.B.; Basri, M. Biodegradation of hydrocarbons in soil by microbial consortium. Int. Biodeterior. Biodegrad. 2004, 54, 61-67. [CrossRef]

42. Goux, S.; Shapir, N.; El Fantroussi, S.; Lelong, S.; Agathos, S.N.; Pussemier, L. Long-term maintenance of rapid atrazine degradation in soils inoculated with atrazine degraders. Water Air Soil Pollut. Focus 2003, 3, 131-142. [CrossRef]

43. Bertin, C.; Yang, X.; Weston, L. The role of root exudates and allelochemicals in the rhizosphere. Plant Soil 2003, 256, 67-83. [CrossRef]

44. Walker, T.S.; Bais, H.P.; Grotewold, E.; Vivanco, J.M. Root exudation and rhizosphere biology. Plant Physiol. 2003, 132, 44-51. [CrossRef] [PubMed]

45. Weston, L.A.; Ryan, P.R.; Watt, M. Mechanisms for cellular transport and release of allelochemicals from plant roots into the rhizosphere. J. Exp. Bot. 2012, 63, 3445-3454. [CrossRef] [PubMed]

46. Huang, X.F.; Chaparro, J.M.; Reardon, K.F.; Zhang, R.F.; Shen, Q.R.; Vivanco, J.M. Rhizosphere interactions: Root exudates, microbes, and microbial communities. Botany 2014, 92, 267-275. [CrossRef]

47. Bowen, G.D.; Rovira, A.D. The rhizosphere and its management to improve plant growth. In Advances in Agronomy; Donald, L.S., Ed.; Academic Press: San Diego, CA, USA, 1999; Volume 66, pp. 1-102.

48. Uren, N. Types, amounts, and possible functions of compounds released into the rhizosphere by soil-grown plants. In The Rhizosphere; CRC Press: New York, NY, USA, 2007; pp. 1-21.

49. Badri, D.V.; Vivanco, J.M. Regulation and function of root exudates. Plant Cell Environ. 2009, 32, 666-681. [CrossRef] [PubMed]

50. Badri, D.V.; Zolla, G.; Bakker, M.G.; Manter, D.K.; Vivanco, J.M. Potential impact of soil microbiomes on the leaf metabolome and on herbivore feeding behavior. New Phytologist 2013, 198, 264-273. [CrossRef] [PubMed]

51. Badri, D.V.; Chaparro, J.M.; Zhang, R.F.; Shen, Q.R.; Vivanco, J.M. Application of natural blends of phytochemicals derived from the root exudates of arabidopsis to the soil reveal that phenolic-related compounds predominantly modulate the soil microbiome. J. Biol. Chem. 2013, 288, 4502. [CrossRef] [PubMed]

52. Lioussanne, L.; Jolicoeur, M.; St-Arnaud, M. Mycorrhizal colonization with glomus intraradices and development stage of transformed tomato roots significantly modify the chemotactic response of zoospores of the pathogen phytophthora nicotianae. Soil Biol. Biochem. 2008, 40, 2217-2224. [CrossRef]

53. Lynch, J.M.; Whipps, J.M. Substrate flow in the rhizosphere. Plant Soil 1990, 129, 1-10. [CrossRef]

54. Martin, B.C.; George, S.J.; Price, C.A.; Ryan, M.H.; Tibbett, M. The role of root exuded low molecular weight organic anions in facilitating petroleum hydrocarbon degradation: Current knowledge and future directions. Sci. Total Environ. 2014, 472, 642-653. [CrossRef] [PubMed] 
55. Marilley, L.; Aragno, M. Phylogenetic diversity of bacterial communities differing in degree of proximity of lolium perenne and trifolium repens roots. Appl. Soil Ecol. 1999, 13, 127-136. [CrossRef]

56. Kowalchuk, G.A.; Buma, D.S.; de Boer, W.; Klinkhamer, P.G.; van Veen, J.A. Effects of above-ground plant species composition and diversity on the diversity of soil-borne microorganisms. Antonie van Leeuwenhoek 2002, 81, 509-520. [CrossRef] [PubMed]

57. Anderson, T.A.; Guthrie, E.A.; Walton, B.T. Bioremediation in the rhizosphere. Environ. Sci. Technol. 1993, 27, 2630-2636. [CrossRef]

58. Cheng, W.X.; Coleman, D.C. Effect of living roots on soil organic-matter decomposition. Soil Biol. Biochem. 1990, 22, 781-787. [CrossRef]

59. Nie, M.; Yang, Q.; Jiang, L.-F.; Fang, C.-M.; Chen, J.-K.; Li, B. Do plants modulate biomass allocation in response to petroleum pollution? Biol. Lett. 2010, 6, 811-814. [CrossRef] [PubMed]

60. Mathesius, U.; Watt, M. Rhizosphere signals for plant-microbe interactions: Implications for field-grown plants. In Progress in Botany 72; Springer: Berlin, Germany, 2010; pp. 125-161.

61. Field, B.; Jordán, F.; Osbourn, A. First encounters-Deployment of defence-related natural products by plants. New Phytol. 2006, 172, 193-207. [CrossRef] [PubMed]

62. Dayan, F.E.; Duke, S.O. Biological activity of allelochemicals. In Plant-Derived Natural Products; Osbourn, A.E., Lanzotti, V., Eds.; Springer: Berlin, Germany, 2009; pp. 361-384.

63. Ben, L. Life of microbes in the rhizosphere. In Principles of Plant-Microbe Interactions-Microbes for Sustainable Agriculture; Lugtenberg, B., Ed.; Springer International Publishing: Berlin, Germany, 2015; pp. 7-15.

64. Heuer, H.; Smalla, K. Plasmids foster diversification and adaptation of bacterial populations in soil. FEMS Microbiol. Rev. 2012, 36, 1083-1104. [CrossRef] [PubMed]

65. Bulgarelli, D.; Schlaeppi, K.; Spaepen, S.; van Themaat, E.V.L.; Schulze-Lefert, P. Structure and functions of the bacterial microbiota of plants. Annu. Rev. Plant Biol. 2013, 64, 807-838. [CrossRef] [PubMed]

66. Favas, P.J.; Pratas, J.; Varun, M.; D'Souza, R.; Paul, M.S. Phytoremediation of soils contaminated with metals and metalloids at mining areas: Potential of native flora. In Environmental Risk Assessment of Soil Contamination; Hernandez-Soriano, M.C., Ed.; InTech: Rijeka, Croatia, 2014; pp. 485-517.

67. Gao, Y.; Yang, Y.; Ling, W.; Kong, H.; Zhu, X. Gradient distribution of root exudates and polycyclic aromatic hydrocarbons in rhizosphere soil. Soil Sci. Soc. Am. J. 2011, 75, 1694-1703. [CrossRef]

68. Corgié, S.; Joner, E.J.; Leyval, C. Rhizospheric degradation of phenanthrene is a function of proximity to roots. Plant Soil 2003, 257, 143-150. [CrossRef]

69. Yang, Y.; Ratte, D.; Smets, B.; Pignatello, J.; Grasso, D. Mobilization of soil organic matter by complexing agents and implications for polycyclic aromatic hydrocarbon desorption. Chemosphere 2001, 43, 1013-1021. [CrossRef]

70. Compant, S.; Clément, C.; Sessitsch, A. Plant growth-promoting bacteria in the rhizo- and endosphere of plants: Their role, colonization, mechanisms involved and prospects for utilization. Soil Biol. Biochem. 2010, 42, 669-678. [CrossRef]

71. Van Loon, L.C.; Bakker, P.A.H.M. Induced systemic resistance as a mechanism of disease suppression by rhizobacteria. In Pgpr: Biocontrol and Biofertilization; Siddiqui, Z., Ed.; Springer: Dordrecht, The Netherlands, 2006; pp. 39-66.

72. Hartmann, A.; Rothballer, M.; Schmid, M. Lorenz hiltner, a pioneer in rhizosphere microbial ecology and soil bacteriology research. Plant Soil 2008, 312, 7-14. [CrossRef]

73. Morgan, J.A.W.; Bending, G.D.; White, P.J. Biological costs and benefits to plant-microbe interactions in the rhizosphere. J. Exp. Bot. 2005, 56, 1729-1739. [CrossRef] [PubMed]

74. Nihorimbere, V.; Ongena, M.; Smargiassi, M.; Thonart, P. Beneficial effect of the rhizosphere microbial community for plant growth and health. Biotechnol. Agron. Soc. Environ. 2011, 15, 327-337.

75. Berg, G.; Smalla, K. Plant species and soil type cooperatively shape the structure and function of microbial communities in the rhizosphere. FEMS Microbiol. Ecol. 2009, 68, 1-13. [CrossRef] [PubMed]

76. Lauber, C.L.; Strickland, M.S.; Bradford, M.A.; Fierer, N. The influence of soil properties on the structure of bacterial and fungal communities across land-use types. Soil Biol. Biochem. 2008, 40, 2407-2415. [CrossRef]

77. Marschner, P.; Yang, C.-H.; Lieberei, R.; Crowley, D. Soil and plant specific effects on bacterial community composition in the rhizosphere. Soil Biol. Biochem. 2001, 33, 1437-1445. [CrossRef]

78. Fierer, N.; Jackson, R.B. The diversity and biogeography of soil bacterial communities. PNAS 2006, 103, 626-631. [CrossRef] [PubMed] 
79. Mahaffee, W.F.; Kloepper, J.W. Temporal changes in the bacterial communities of soil, rhizosphere, and endorhiza associated with field-grown cucumber (cucumis sativus 1.). Microb. Ecol. 1997, 34, 210-223. [CrossRef] [PubMed]

80. Kuzyakov, Y. Factors affecting rhizosphere priming effects. J. Plant Nutr. Soil Sci. 2002, 165, 382-396. [CrossRef]

81. Broeckling, C.D.; Broz, A.K.; Bergelson, J.; Manter, D.K.; Vivanco, J.M. Root exudates regulate soil fungal community composition and diversty. Appl. Environ. Microbiol. 2008, 74, 738-744. [CrossRef] [PubMed]

82. Bulgarelli, D.; Rott, M.; Schlaeppi, K.; van Themaat, E.V.L.; Ahmadinejad, N.; Assenza, F.; Rauf, P.; Huettel, B.; Reinhardt, R.; Schmelzer, E.; et al. Revealing structure and assembly cues for arabidopsis root-inhabiting bacterial microbiota. Nature 2012, 488, 91-95. [CrossRef] [PubMed]

83. Lundberg, D.S.; Lebeis, S.L.; Paredes, S.H.; Yourstone, S.; Gehring, J.; Malfatti, S.; Tremblay, J.; Engelbrektson, A.; Kunin, V.; del Rio, T.G.; et al. Defining the core arabidopsis thaliana root microbiome. Nature 2012, 488, 86-90. [CrossRef] [PubMed]

84. Micallef, S.A.; Shiaris, M.P.; Colon-Carmona, A. Influence of arabidopsis thaliana accessions on rhizobacterial communities and natural variation in root exudates. J. Exp. Bot. 2009, 60, 1729-1742. [CrossRef] [PubMed]

85. Micallef, S.A.; Channer, S.; Shiaris, M.P.; Colon-Carmona, A. Plant age and genotype impact the progression of bacterial community succession in the arabidopsis rhizosphere. Plant Signal. Behav. 2009, 4, 777-780. [CrossRef] [PubMed]

86. Chaparro, J.M.; Badri, D.V.; Vivanco, J.M. Rhizosphere microbiome assemblage is affected by plant development. ISME J. 2014, 8, 790-803. [CrossRef] [PubMed]

87. Inceoglu, O.; Abu Al-Soud, W.; Salles, J.F.; Semenov, A.V.; van Elsas, J.D. Comparative analysis of bacterial communities in a potato field as determined by pyrosequencing. PLoS ONE 2011, 6, e23321. [CrossRef] [PubMed]

88. Carvalhais, L.C.; Dennis, P.G.; Badri, D.V.; Tyson, G.W.; Vivanco, J.M.; Schenk, P.M. Activation of the jasmonic acid plant defence pathway alters the composition of rhizosphere bacterial communities. PLoS ONE 2013, 8, e56457. [CrossRef] [PubMed]

89. Berendsen, R.L.; Pieterse, C.M.J.; Bakker, P.A.H.M. The rhizosphere microbiome and plant health. Trends Plant Sci. 2012, 17, 478-486. [CrossRef] [PubMed]

90. Vandenkoornhuyse, P.; Quaiser, A.; Duhamel, M.; Le Van, A.; Dufresne, A. The importance of the microbiome of the plant holobiont. New Phytol. 2015, 206, 1196-1206. [CrossRef] [PubMed]

91. Zilber-Rosenberg, I.; Rosenberg, E. Role of microorganisms in the evolution of animals and plants: The hologenome theory of evolution. FEMS Microbiol. Rev. 2008, 32, 723-735. [CrossRef] [PubMed]

92. Bordenstein, S.R.; Theis, K.R. Host biology in light of the microbiome: Ten principles of holobionts and hologenomes. PLoS Biol. 2015, 13, e1002226. [CrossRef] [PubMed]

93. Weston, L.A.; Skoneczny, D.; Weston, P.A.; Weidenhamer, J.D. Metabolic profiling: An overview-New approaches for the detection and functional analysis of biologically active secondary plant products. J. Allelochem. Interact. 2015, 1, 15-27.

94. Rosenberg, E.; Zilber-Rosenberg, I. The Hologenome Concept: Human, Animal and Plant Microbiota; Springer: Berlin, Germany, 2013.

95. Guerrero, R.; Margulis, L.; Berlanga, M. Symbiogenesis: The holobiont as a unit of evolution. Int. Microbiol. 2013, 16, 133-143. [PubMed]

96. Kiers, E.T.; van der Heijden, M.G. Mutualistic stability in the arbuscular mycorrhizal symbiosis: Exploring hypotheses of evolutionary cooperation. Ecology 2006, 87, 1627-1636. [CrossRef]

97. Somers, E.; Vanderleyden, J.; Srinivasan, M. Rhizosphere bacterial signalling: A love parade beneath our feet. Crit. Rev. Microbiol. 2004, 30, 205-240. [CrossRef] [PubMed]

98. Singh, B.K.; Millard, P.; Whiteley, A.S.; Murrell, J.C. Unravelling rhizosphere-microbial interactions: Opportunities and limitations. Trends Microbiol. 2004, 12, 386-393. [CrossRef] [PubMed]

99. Jones, K.M.; Kobayashi, H.; Davies, B.W.; Taga, M.E.; Walker, G.C. How rhizobial symbionts invade plants: The sinorhizobium-medicago model. Nat. Rev. Microbiol. 2007, 5, 619-633. [CrossRef] [PubMed]

100. Smith, K.P.; Handelsman, J.; Goodman, R.M. Genetic basis in plants for interactions with disease-suppressive bacteria. PNAS 1999, 96, 4786-4790. [CrossRef] [PubMed]

101. Stougaard, J. Regulators and regulation of legume root nodule development. Plant Physiol. 2000, 124, 531-540. [CrossRef] [PubMed] 
102. Egamberdieva, D.; Kamilova, F.; Validov, S.; Gafurova, L.; Kucharova, Z.; Lugtenberg, B. High incidence of plant growth-stimulating bacteria associated with the rhizosphere of wheat grown on salinated soil in uzbekistan. Environ. Microbiol. 2008, 10, 1-9. [CrossRef] [PubMed]

103. Ma, B.; He, Y.; Chen, H.-H.; Xu, J.-M.; Rengel, Z. Dissipation of polycyclic aromatic hydrocarbons (PAHS) in the rhizosphere: Synthesis through meta-analysis. Environ. Pollut. 2010, 158, 855-861. [CrossRef] [PubMed]

104. Germida, J.J.; Frick, C.M.; Farrell, R.E. Phytoremediation of oil-contaminated soils. In Soil Mineral-Organic Matter-Microorganism Interactions and Ecosystem Health, Volume 28b: Ecological Significance of the Interactions among Clay Minerals, Organic Matter and Soil Biota; Violante, A., Huang, P.M., Bollag, J.M., Gianfreda, L., Eds.; 2002; Volume 28B, pp. 169-186.

105. Atlas, R.; Bragg, J. Bioremediation of marine oil spills: When and when not-The exxon valdez experience. Microb. Biotechnol. 2009, 2, 213-221. [CrossRef] [PubMed]

106. Pelletier, E.; Delille, D.; Delille, B. Crude oil bioremediation in sub-antarctic intertidal sediments: Chemistry and toxicity of oiled residues. Mar. Environ. Res. 2004, 57, 311-327. [CrossRef] [PubMed]

107. Delille, D.; Coulon, F.; Pelletier, E. Effects of temperature warming during a bioremediation study of natural and nutrient-amended hydrocarbon-contaminated sub-antarctic soils. Cold Reg. Sci. Technol. 2004, 40, 61-70. [CrossRef]

108. Foght, J.M.; Westlake, D.W.; Johnson, W.M.; Ridgway, H.F. Environmental gasoline-utilizing isolates and clinical isolates of pseudomonas aeruginosa are taxonomically indistinguishable by chemotaxonomic and molecular techniques. Microbiology 1996, 142, 2333-2340. [CrossRef] [PubMed]

109. Venosa, A.D.; Zhu, X. Biodegradation of crude oil contaminating marine shorelines and freshwater wetlands. Spill Sci. Technol. Bull. 2003, 8, 163-178. [CrossRef]

110. Margesin, R.; Schinner, F. Biodegradation and bioremediation of hydrocarbons in extreme environments. Appl. Microbiol. Biotechnol. 2001, 56, 650-663. [CrossRef] [PubMed]

111. Zhou, E.; Crawford, R. Effects of oxygen, nitrogen, and temperature on gasoline biodegradation in soil. Biodegradation 1995, 6, 127-140. [CrossRef] [PubMed]

112. Coulon, F.; Pelletier, E.; Gourhant, L.; Delille, D. Effects of nutrient and temperature on degradation of petroleum hydrocarbons in contaminated sub-antarctic soil. Chemosphere 2005, 58, 1439-1448. [CrossRef] [PubMed]

113. Chaineau, C.; Rougeux, G.; Yepremian, C.; Oudot, J. Effects of nutrient concentration on the biodegradation of crude oil and associated microbial populations in the soil. Soil Biol. Biochem. 2005, 37, 1490-1497. [CrossRef]

114. Tibbett, M.; George, S.J.; Davie, A.; Barron, A.; Milton, N.; Greenwood, P.F. Just add water and salt: The optimisation of petrogenic hydrocarbon biodegradation in soils from semi-arid barrow island, western Australia. Water Air Soil Pollut. Focus 2011, 216, 513-525. [CrossRef]

115. Chaillan, F.; Chaineau, C.; Point, V.; Saliot, A.; Oudot, J. Factors inhibiting bioremediation of soil contaminated with weathered oils and drill cuttings. Environ. Pollut. 2006, 144, 255-265. [CrossRef] [PubMed]

116. Oudot, J.; Merlin, F.; Pinvidic, P. Weathering rates of oil components in a bioremediation experiment in estuarine sediments. Mar. Environ. Res. 1998, 45, 113-125. [CrossRef]

117. Carmichael, L.M.; Pfaender, F.K. The effect of inorganic and organic supplements on the microbial degradation of phenanthrene and pyrene in soils. Biodegradation 1997, 8, 1-13. [CrossRef] [PubMed]

118. Chaudhry, Q.; Blom-Zandstra, M.; Gupta, S.; Joner, E.J. Utilising the synergy between plants and rhizosphere microorganisms to enhance breakdown of organic pollutants in the environment. Environ. Sci. Pollut. Res. Int. 2005, 12, 34-48. [CrossRef] [PubMed]

119. Macek, T.; Mackova, M.; Kas, J. Exploitation of plants for the removal of organics in environmental remediation. Biotechnol. Adv. 2000, 18, 23-34. [CrossRef]

120. Yateem, A.; Al-Sharrah, T.; Bin-Haji, A. Investigation of microbes in the rhizosphere of selected trees for the rhizoremediation of hydrocarbon-contaminated soils. Int. J. Phytoremediation 2008, 10, 311-324. [CrossRef] [PubMed]

121. Peixoto, R.; Vermelho, A.; Rosado, A. Petroleum-degrading enzymes: Bioremediation and new prospects. Enzyme Res. 2011, 2011. [CrossRef] [PubMed]

122. Hassanshahian, M.; Cappello, S. Crude oil biodegradation in the marine environments. In Biodegradation-Engineering and Technology; Chamy, R., Rosenkranz, F., Eds.; InTech: Rijeka, Croatia, 2013. 
123. Sierra-Garcia, I.N.; Oliveira, V.M.D. Microbial Hydrocarbon Degradation: Efforts to Understand Biodegradation in Petroleum Reservoirs. In Biodegradation-Engineering and Technology; Chamy, R., Rosenkranz, F., Eds.; InTech: Rijeka, Croatia, 2013; pp. 47-72.

124. Orphan, V.; Goffredi, S.K.; Delong, E.; Boles, J. Geochemical influence on diversity and microbial processes in high temperature oil reservoirs. Geomicrobiol. J. 2003, 20, 295-311. [CrossRef]

125. Nazina, T.; Shestakova, N.; Grigor'yan, A.; Mikhailova, E.; Tourova, T.; Poltaraus, A.; Feng, C.; Ni, F.; Belyaev, S. Phylogenetic diversity and activity of anaerobic microorganisms of high-temperature horizons of the Dagang oil field (PR China). Microbiology 2006, 75, 55-65. [CrossRef]

126. Garcia, J.-L.; Patel, B.K.; Ollivier, B. Taxonomic, phylogenetic, and ecological diversity of methanogenic archaea. Anaerobe 2000, 6, 205-226. [CrossRef] [PubMed]

127. Zinder, S.H.; Koch, M. Non-aceticlastic methanogenesis from acetate: Acetate oxidation by a thermophilic syntrophic coculture. Arch. Microbiol. 1984, 138, 263-272. [CrossRef]

128. Hattori, S.; Kamagata, Y.; Hanada, S.; Shoun, H. Thermacetogenium phaeum gen. Nov., sp. Nov., a strictly anaerobic, thermophilic, syntrophic acetate-oxidizing bacterium. Int. J. Syst. Evol. Microbiol. 2000, 50, 1601-1609. [CrossRef] [PubMed]

129. Balk, M.; Weijma, J.; Stams, A.J. Thermotoga lettingae sp. Nov., a novel thermophilic, methanol-degrading bacterium isolated from a thermophilic anaerobic reactor. Int. J. Syst. Evol. Microbiol. 2002, 52, 1361-1368. [CrossRef] [PubMed]

130. Hopwood, D.A.; Chater, K.F. Genetics of Bacterial Diversity; Elsevier Science: Philadelphia, PA, USA, 1988.

131. Kothari, V.; Panchal, M.; Srivastava, N. Microbial Degradation of Hydrocarbons; Institute of Science: Nirma University, Ahmedabad, Gujarat, India, 2013.

132. Guzik, U.; Hupert-Kocurek, K.; Wojcieszyńska, D. Intradiol dioxygenases-The key enzymes in xenobiotics degradation. In Biodegradation of Hazardous and Special Products; Chamy, R., Rosenkranz, F., Eds.; InTech: Rijeka, Croatia, 2013.

133. Segura, A.; Ramos, J.L. Plant-bacteria interactions in the removal of pollutants. Curr. Opin. Biotechnol. 2013, 24, 467-473. [CrossRef] [PubMed]

134. Van Hamme, J.D.; Singh, A.; Ward, O.P. Recent advances in petroleum microbiology. Microbiol. Mol. Biol. Rev. 2003, 67, 503-549. [CrossRef] [PubMed]

135. Weelink, S.B.; van Eekert, M.A.; Stams, A.M. Degradation of Btex by anaerobic bacteria: Physiology and application. Rev. Environ. Sci. Bio/Technol. 2010, 9, 359-385. [CrossRef]

136. Zhang, C.; Bennett, G. Biodegradation of xenobiotics by anaerobic bacteria. Appl. Microbiol. Biotechnol. 2005, 67, 600-618. [CrossRef] [PubMed]

137. Foght, J. Anaerobic biodegradation of aromatic hydrocarbons: Pathways and prospects. J. Mol. Microbiol. Biotechnol. 2008, 15, 93-120. [CrossRef] [PubMed]

138. Jaekel, U.; Zedelius, J.; Wilkes, H.; Musat, F. Anaerobic degradation of cyclohexane by sulfate-reducing bacteria from hydrocarbon-contaminated marine sediments. Front. Microbiol. 2015, 6, 116. [CrossRef] [PubMed]

139. Narasimhan, K.; Basheer, C.; Bajic, V.B.; Swarup, S. Enhancement of plant-microbe interactions using a rhizosphere metabolomics-driven approach and its application in the removal of polychlorinated biphenyls. Plant Physiol. 2003, 132, 146-153. [CrossRef] [PubMed]

140. Yan-Zheng, G.; Li-Zhong, Z. Phytoremediation for phenanthrene- and pyrene-contaminated soils. J. Environ. Sci. (China) 2005, 17, 14-18.

141. Joner, E.J.; Leyval, C. Rhizosphere gradients of polycyclic aromatic hydrocarbon (PAH) dissipation in two industrial soils and the impact of arbuscular mycorrhiza. Environ. Sci. Technol. 2003, 37, 2371-2375. [CrossRef] [PubMed]

142. Bais, H.P.; Weir, T.L.; Perry, L.G.; Gilroy, S.; Vivanco, J.M. The role of root exudates in rhizosphere interactions with plants and other organisms. Annu. Rev. Plant Biol. 2006, 57, 233-266. [CrossRef] [PubMed]

143. Ryan, P.; Delhaize, E.; Jones, D. Function and mechanism of organic anion exudation from plant roots. Annu. Rev. Plant Biol. 2001, 52, 527-560. [CrossRef] [PubMed]

144. Neumann, G. Root exudates and nutrient cycling. In Nutrient Cycling in Terrestrial Ecosystems; Marschner, P., Rengel, Z., Eds.; Springer: Berlin, Germany, 2007; Volume 10, pp. 123-157.

145. Gransee, A.; Wittenmayer, L. Qualitative and quantitative analysis of water-soluble root exudates in relation to plant species and development. J. Plant Nutr. Soil Sci. 2000, 163, 381-385. [CrossRef] 
146. Hutsch, B.W.; Augustin, J.; Merbach, W. Plant rhizodeposition-An important source for carbon turnover in soils. J. Plant Nutr. Soil Sci. 2002, 165, 397-407. [CrossRef]

147. Leigh, M.B.; Fletcher, J.S.; Fu, X.O.; Schmitz, F.J. Root turnover: An important source of microbial substrates in rhizosphere remediation of recalcitrant contaminants. Environ. Sci. Technol. 2002, 36, 1579-1583. [CrossRef] [PubMed]

148. Shukla, K.P.; Sharma, S.; Singh, N.K.; Singh, V.; Tiwari, K.; Singh, A.S. Nature and role of root exudates: Efficacy in bioremediation. Afr. J. Biotechnol. 2011, 10, 9717-9724.

149. Xue, K.; Wu, L.; Deng, Y.; He, Z.; Van Nostrand, J.; Robertson, P.G.; Schmidt, T.M.; Zhou, J. Functional gene differences in soil microbial communities from conventional, low-input, and organic farmlands. Appl. Environ. Microbiol. 2013, 79, 1284-1292. [CrossRef] [PubMed]

150. Marschner, P.; Crowley, D.; Rengel, Z. Rhizosphere interactions between microorganisms and plants govern iron and phosphorus acquisition along the root axis-Model and research methods. Soil Biol. Biochem. 2011, 43, 883-894. [CrossRef]

151. Gao, Y.; He, J.; Ling, W.; Hu, H.; Liu, F. Effects of organic acids on copper and cadmium desorption from contaminated soils. Environ. Int. 2003, 29, 613-618. [CrossRef]

152. Van Hees, P.A.; Jones, D.L.; Jentschke, G.; Godbold, D.L. Organic acid concentrations in soil solution: Effects of young coniferous trees and ectomycorrhizal fungi. Soil Biol. Biochem. 2005, 37, 771-776. [CrossRef]

153. Cooper, G. The Cell: A Molecular Approach, 2nd ed.; Sinauer Associates: Sunderland, MA, USA, 2000.

154. Campbell, A.K. Intracellular Calcium; Wiley: Hoboken, NJ, USA, 2014.

155. Sanders, D.; Bethke, P. Membrane transport. In Biochemistry and Molecular Biology of Plants, 2nd ed.; Buchanan, B.B., Gruissem, W., Jones, R.L., Eds.; 2000; pp. 110-158.

156. Guern, J.; Renaudin, J.P.; Brown, S.C. The compartimentation of secondary metabolites in plant cell cultures. In Cell Culture and Somatic Cell Genetics of Plants; Vasil, I.K., Ed.; Academic Press: San Diego, CA, USA, 1987; pp. 43-76.

157. Hussain, D.; Haydon, M.J.; Wang, Y.; Wong, E.; Sherson, S.M.; Young, J.; Camakaris, J.; Harper, J.F.; Cobbett, C.S. P-type ATPase heavy metal transporters with roles in essential zinc homeostasis in arabidopsis. Plant Cell 2004, 16, 1327-1339. [CrossRef] [PubMed]

158. Williams, L.E.; Pittman, J.K.; Hall, J.L. Emerging mechanisms for heavy metal transport in plants. Biochim. Et Biophys. Acta Biomembr. 2000, 1465, 104-126. [CrossRef]

159. Colangelo, E.P.; Guerinot, M.L. Put the metal to the petal: Metal uptake and transport throughout plants. Curr. Opin. Plant Biol. 2006, 9, 322-330. [CrossRef] [PubMed]

160. Hoekenga, O.A.; Maron, L.G.; Pineros, M.A.; Cancado, G.M.A.; Shaff, J.; Kobayashi, Y.; Ryan, P.R.; Dong, B.; Delhaize, E.; Sasaki, T.; et al. Atalmt1, which encodes a malate transporter, is identified as one of several genes critical for aluminum tolerance in arabidopsis. PNAS 2006, 103, 9738-9743. [CrossRef] [PubMed]

161. Lee, Y.H.; Foster, J.; Chen, J.; Voll, L.M.; Weber, A.P.M.; Tegeder, M. Aap1 transports uncharged amino acids into roots of arabidopsis. Plant J. 2007, 50, 305-319. [CrossRef] [PubMed]

162. Svennerstam, H.; Ganeteg, U.; Bellini, C.; Nasholm, T. Comprehensive screening of arabidopsis mutants suggests the lysine histidine transporter 1 to be involved in plant uptake of amino acids. Plant Physiol. 2007, 143, 1853-1860. [CrossRef] [PubMed]

163. Haydon, M.J.; Cobbett, C.S. Transporters of ligands for essential metal ions in plants. New Phytol. 2007, 174, 499-506. [CrossRef] [PubMed]

164. Curie, C.; Briat, J.F. Iron transport and signaling in plants. Annu. Rev. Plant Biol. 2003, 54, 183-206. [CrossRef] [PubMed]

165. Curie, C.; Panaviene, Z.; Loulergue, C.; Dellaporta, S.L.; Briat, J.F.; Walker, E.L. Maize yellow stripe1 encodes a membrane protein directly involved in Fe(iii) uptake. Nature 2001, 409, 346-349. [CrossRef] [PubMed]

166. Dixon, R.A. Natural products and plant disease resistance. Nature 2001, 411, 843-847. [CrossRef] [PubMed]

167. Battey, N.H.; Blackbourn, H.D. The control of exocitosis in plant cells. New Phytol. 1993, 125, 307-308. [CrossRef]

168. Yazaki, K. Transporters of secondary metabolites. Curr. Opin. Plant Biol. 2005, 8, 301-307. [CrossRef] [PubMed]

169. Yazaki, K.; Matsuoka, H.; Shimomura, K.; Bechthold, A.; Sato, F. A novel dark-inducible protein, Ledi-2, and its involvement in root-specific secondary metabolism in lithospermum erythrorhizon. Plant Physiol. 2001, 125, 1831-1841. [CrossRef] [PubMed] 
170. Brigham, L.A.; Woo, H.-H.; Wen, F.; Hawes, M.C. Meristem-specific suppression of mitosis and a global switch in gene expression in the root cap of pea by endogenous signals. Plant Physiol. 1998, 118, 1223-1231. [CrossRef] [PubMed]

171. Neumann, G.; Romheld, V. The release of root exudates as affected by the plant's physiological status. In The Rhizosphere, Biochemistry and Organic Substances at the Soil-Plant Interface; Pinton, R., Varanini, Z., Nannipieri, P., Eds.; Marcel Dekker: New York, NY, USA, 2000; pp. 41-93.

172. Badri, D.V.; Quintana, N.; El Kassis, E.G.; Kim, H.K.; Choi, Y.H.; Sugiyama, A.; Verpoorte, R.; Martinoia, E.; Manter, D.K.; Vivanco, J.M. An Abc transporter mutation alters root exudation of phytochemicals that provoke an overhaul of natural soil microbiota. Plant Physiol. 2009, 151, 2006-2017. [CrossRef] [PubMed]

173. Loyola-Vargas, V.M.; Broeckling, C.D.; Badri, D.; Vivanco, J.M. Effect of transporters on the secretion of phytochemicals by the roots of arabidopsis thaliana. Planta 2007, 225, 301-310. [CrossRef] [PubMed]

174. Sugiyama, A.; Shitan, N.; Yazaki, K. Signaling from soybean roots to rhizobium: An ATP-binding cassette-type transporter mediates genistein secretion. Plant Signal. Behav. 2008, 3, 38-40. [CrossRef] [PubMed]

175. Reddy, V.S.; Shlykov, M.A.; Castillo, R.; Sun, E.I.; Saier, M.H., Jr. The major facilitator superfamily (MFS) revisited. FEBS J. 2012, 279, 2022-2035. [CrossRef] [PubMed]

176. Diener, A.C.; Gaxiola, R.A.; Fink, G.R. Arabidopsis Alf5, a multidrug efflux transporter gene family member, confers resistance to toxins. Plant Cell 2001, 13, 1625-1638. [CrossRef] [PubMed]

177. Li, L.; He, Z.; Pandey, G.K.; Tsuchiya, T.; Luan, S. Functional cloning and characterization of a plant efflux carrier for multidrug and heavy metal detoxification. J. Biol. Chem. 2002, 277, 5360-5368. [CrossRef] [PubMed]

178. Liu, J.; Magalhaes, J.V.; Shaff, J.; Kochian, L.V. Aluminum-activated citrate and malate transporters from the mate and Almt families function independently to confer arabidopsis aluminum tolerance. Plant J. 2009, 57, 389-399. [CrossRef] [PubMed]

179. Magalhaes, J.V.; Liu, J.; Guimaraes, C.T.; Lana, U.G.; Alves, V.M.; Wang, Y.H.; Schaffert, R.E.; Hoekenga, O.A.; Pineros, M.A.; Shaff, J.E.; et al. A gene in the multidrug and toxic compound extrusion (mate) family confers aluminum tolerance in sorghum. Nat. Genet. 2007, 39, 1156-1161. [CrossRef] [PubMed]

180. Furukawa, J.; Yamaji, N.; Wang, H.; Mitani, N.; Murata, Y.; Sato, K.; Katsuhara, M.; Takeda, K.; Ma, J.F. An aluminum-activated citrate transporter in barley. Plant Cell. Physiol. 2007, 48, 1081-1091. [CrossRef] [PubMed]

181. Ishimaru, Y.; Kakei, Y.; Shimo, H.; Bashir, K.; Sato, Y.; Uozumi, N.; Nakanishi, H.; Nishizawa, N.K. A rice phenolic efflux transporter is essential for solubilizing precipitated apoplasmic iron in the plant stele. J. Biol. Chem. 2011, 286, 24649-24655. [CrossRef] [PubMed]

182. Rentz, J.A.; Alvarez, P.J.; Schnoor, J.L. Benzo (a)pyrene co-metabolism in the presence of plant root extracts and exudates: Implications for phytoremediation. Environ. Pollut. 2005, 136, 477-484. [CrossRef] [PubMed]

183. Johnson, D.; Anderson, D.; McGrath, S. Soil microbial response during the phytoremediation of a PAH contaminated soil. Soil Biol. Biochem. 2005, 37, 2334-2336. [CrossRef]

184. Yang, C.-H.; Crowley, D.E. Rhizosphere microbial community structure in relation to root location and plant iron nutritional status. Appl. Environ. Microbiol. 2000, 66, 345-351. [CrossRef] [PubMed]

185. Jones, D.L.; Hodge, A.; Kuzyakov, Y. Plant and mycorrhizal regulation of rhizodeposition. New Phytol. 2004, 163, 459-480. [CrossRef]

186. Singh, B.K.; Munro, S.; Potts, J.M.; Millard, P. Influence of grass species and soil type on rhizosphere microbial community structure in grassland soils. Appl. Soil Ecol. 2007, 36, 147-155. [CrossRef]

187. Bonanomi, G.; Vinale, F.; Scala, F. The role of natural products in plant-microbe interactions. In Plant-Derived Natural Products; Osbourn, A.E., Lanzotti, V., Eds.; Springer: Berlin, Germany, 2009; pp. 301-320.

188. Zhou, X.G.; Wu, F.Z. P-coumaric acid influenced cucumber rhizosphere soil microbial communities and the growth of fusarium oxysporum f.Sp cucumerinum owen. PLoS ONE 2012, 7. [CrossRef] [PubMed]

189. Zhou, X.G.; Wu, F.Z. Artificially applied vanillic acid changed soil microbial communities in the rhizosphere of cucumber (cucumis sativus 1.). Can. J. Soil Sci. 2013, 93, 13-21. [CrossRef]

190. Gao, M.S.; Teplitski, M.; Robinson, J.B.; Bauer, W.D. Production of substances by medicago truncatula that affect bacterial quorum sensing. Mol. Plant Microbe Interact. 2003, 16, 827-834. [CrossRef] [PubMed] 
191. Teplitski, M.; Robinson, J.B.; Bauer, W.D. Plants secrete substances that mimic bacterial N-acyl homoserine lactone signal activities and affect population density-dependent behaviors in associated bacteria. Mol. Plant Microbe Interact. 2000, 13, 637-648. [CrossRef] [PubMed]

192. Knee, E.M.; Gong, F.C.; Gao, M.S.; Teplitski, M.; Jones, A.R.; Foxworthy, A.; Mort, A.J.; Bauer, W.D. Root mucilage from pea and its utilization by rhizosphere bacteria as a sole carbon source. Mol. Plant Microbe Interact. 2001, 14, 775-784. [CrossRef] [PubMed]

193. Daniels, R.; De Vos, D.E.; Desair, J.; Raedschelders, G.; Luyten, E.; Rosemeyer, V.; Verreth, C.; Schoeters, E.; Vanderleyden, J.; Michiels, J. The cin quorum sensing locus of rhizobium etli CNPAF512 affects growth and symbiotic nitrogen fixation. J. Biol. Chem. 2002, 277, 462-468. [CrossRef] [PubMed]

194. Teplitski, M.; Chen, H.C.; Rajamani, S.; Gao, M.S.; Merighi, M.; Sayre, R.T.; Robinson, J.B.; Rolfe, B.G.; Bauer, W.D. Chlamydomonas reinhardtii secretes compounds that mimic bacterial signals and interfere with quorum sensing regulation in bacteria. Plant Physiol. 2004, 134, 137-146. [CrossRef] [PubMed]

195. Proust, H.; Hoffmann, B.; Xie, X.N.; Yoneyama, K.; Schaefer, D.G.; Yoneyama, K.; Nogue, F.; Rameau, C. Strigolactones regulate protonema branching and act as a quorum sensing-like signal in the moss physcomitrella patens. Development 2011, 138, 1531-1539. [CrossRef] [PubMed]

196. Baudoin, E.; Benizri, E.; Guckert, A. Impact of artificial root exudates on the bacterial community structure in bulk soil and maize rhizosphere. Soil Biol. Biochem. 2003, 35, 1183-1192. [CrossRef]

197. Benizri, E.; Dedourge, O.; Dibattista-Leboeuf, C.; Piutti, S.; Nguyen, C.; Guckert, A. Effect of maize rhizodeposits on soil microbial community structure. Appl. Soil Ecol. 2002, 21, 261-265. [CrossRef]

198. Butler, J.L.; Williams, M.A.; Bottomley, P.J.; Myrold, D.D. Microbial community dynamics associated with rhizosphere carbon flow. Appl. Environ. Microbiol. 2003, 69, 6793-6800. [CrossRef] [PubMed]

199. Hartmann, A.; Schmid, M.; van Tuinen, D.; Berg, G. Plant-driven selection of microbes. Plant Soil 2009, 321, 235-257. [CrossRef]

200. Bakker, M.G.; Manter, D.K.; Sheflin, A.M.; Weir, T.L.; Vivanco, J.M. Harnessing the rhizosphere microbiome through plant breeding and agricultural management. Plant Soil 2012, 360, 1-13. [CrossRef]

201. Chaparro, J.M.; Sheflin, A.M.; Manter, D.K.; Vivanco, J.M. Manipulating the soil microbiome to increase soil health and plant fertility. Biol. Fertil. Soils 2012, 48, 489-499. [CrossRef]

202. De Weert, S.; Vermeiren, H.; Mulders, I.H.M.; Kuiper, I.; Hendrickx, N.; Bloemberg, G.V.; Vanderleyden, J.; De Mot, R.; Lugtenberg, B.J.J. Flagella-driven chemotaxis towards exudate components is an important trait for tomato root colonization by pseudomonas fluorescens. Mol. Plant Microbe Interact. 2002, 15, 1173-1180. [CrossRef] [PubMed]

203. Oku, S.; Komatsu, A.; Tajima, T.; Nakashimada, Y.; Kato, J. Identification of chemotaxis sensory proteins for amino acids in pseudomonas fluorescens PfO-1 and their involvement in chemotaxis to tomato root exudate and root colonization. Microbes Environ. 2012, 27, 462-469. [CrossRef] [PubMed]

204. Rudrappa, T.; Czymmek, K.J.; Pare, P.W.; Bais, H.P. Root-secreted malic acid recruits beneficial soil bacteria. Plant Physiol. 2008, 148, 1547-1556. [CrossRef] [PubMed]

205. Vicre, M.; Santaella, C.; Blanchet, S.; Gateau, A.; Driouich, A. Root border-like cells of arabidopsis. Microscopical characterization and role in the interaction with rhizobacteria. Plant Physiol. 2005, 138, 998-1008. [CrossRef] [PubMed]

206. Martens, D.A. Relationship between plant phenolic acids released during soil mineralization and aggregate stabilization. Soil Sci. Soc. Am. J. 2002, 66, 1857-1867. [CrossRef]

207. Mandal, S.M.; Chakraborty, D.; Dey, S. Phenolic acids act as signaling molecules in plant-microbe symbioses. Plant Signal. Behav. 2010, 5, 359-368. [CrossRef] [PubMed]

208. Fang, C.X.; Zhuang, Y.E.; Xu, T.C.; Li, Y.Z.; Li, Y.; Lin, W.X. Changes in rice allelopathy and rhizosphere microflora by inhibiting rice phenylalanine ammonia-lyase gene expression. J. Chem. Ecol. 2013, 39, $204-212$. [CrossRef] [PubMed]

209. Michalet, S.; Rohr, J.; Warshan, D.; Bardon, C.; Rogy, J.C.; Domenach, A.M.; Czarnes, S.; Pommier, T.; Combourieu, B.; Guillaumaud, N.; et al. Phytochemical analysis of mature tree root exudates in situ and their role in shaping soil microbial communities in relation to tree $\mathrm{N}$-acquisition strategy. Plant Physiol. Biochem. 2013, 72, 169-177. [CrossRef] [PubMed]

210. Blum, U.; Staman, K.L.; Flint, L.J.; Shafer, S.R. Induction and/or selection of phenolic acid-utilizing bulk-soil and rhizosphere bacteria and their influence on phenolic acid phytotoxicity. J. Chem. Ecol. 2000, 26, 2059-2078. [CrossRef] 
211. Van Rossum, D.; Schuurmans, F.P.; Gillis, M.; Muyotcha, A.; Van Verseveld, H.W.; Stouthamer, A.H.; Boogerd, F.C. Genetic and phenetic analyses of bradyrhizobium strains nodulating peanut (arachis hypogaea 1.) roots. Appl. Environ. Microbiol. 1995, 61, 1599-1609. [PubMed]

212. Irisarri, P.; Milnitsky, F.; Monza, J.; Bedmar, E. Characterization of rhizobia nodulating lotus subbiflorus from Uruguayan soils. Plant Soil 1996, 180, 39-47. [CrossRef]

213. Mandal, S.; Mandal, M.; Das, A.; Pati, B.; Ghosh, A. Stimulation of indoleacetic acid production in a rhizobium isolate of vigna mungo by root nodule phenolic acids. Arch. Microbiol. 2009, 191, 389-393. [CrossRef] [PubMed]

214. Weston, L.A.; Mathesius, U. Flavonoids: Their structure, biosynthesis and role in the rhizosphere, including allelopathy. J. Chem. Ecol. 2013, 39, 283-297. [CrossRef] [PubMed]

215. Weston, L.A.; Mathesius, U. Root exudation: The role of secondary metabolites, their localisation in roots and transport into the rhizosphere. In Root Engineering; Springer: Berlin, Germany, 2014; pp. 221-247.

216. Weston, L.A.; Alsaadawi, I.S.; Baerson, S.R. Sorghum allelopathy-From ecosystem to molecule. J. Chem. Ecol. 2013, 39, 142-153. [CrossRef] [PubMed]

217. Neal, A.L.; Ahmad, S.; Gordon-Weeks, R.; Ton, J. Benzoxazinoids in root exudates of maize attract pseudomonas putida to the rhizosphere. PLoS ONE 2012, 7. [CrossRef] [PubMed]

218. Abdel-Lateif, K.; Bogusz, D.; Hocher, V. The role of flavonoids in the establishment of plant roots endosymbioses with arbuscular mycorrhiza fungi, rhizobia and frankia bacteria. Plant Signal. Behav. 2012, 7, 636-641. [CrossRef] [PubMed]

219. Spaepen, S.; Vanderleyden, J. Auxin and plant-microbe interactions. Cold Spring Harbor Perspect. Biol. 2011, 3, a001438. [CrossRef] [PubMed]

220. Chakraborty, D.; Mandal, S.M. Fractional changes in phenolic acids composition in root nodules of arachis hypogaea 1. Plant Growth Regul. 2008, 55, 159-163. [CrossRef]

221. Wen, F.S.; VanEtten, H.D.; Tsaprailis, G.; Hawes, M.C. Extracellular proteins in pea root tip and border cell exudates. Plant Physiol. 2007, 143, 773-783. [CrossRef] [PubMed]

222. De-La-Pena, C.; Lei, Z.; Watson, B.S.; Sumner, L.W.; Vivanco, J.M. Root-microbe communication through protein secretion. J. Biol. Chem. 2008, 283, 25247-25255. [CrossRef] [PubMed]

223. De Hoff, P.; Brill, L.; Hirsch, A. Plant lectins: The ties that bind in root symbiosis and plant defense. Mol. Genet. Genom. 2009, 282, 1-15. [CrossRef] [PubMed]

224. De-la-Pena, C.; Badri, D.V.; Lei, Z.T.; Watson, B.S.; Brandao, M.M.; Silva-Filho, M.C.; Sumner, L.W.; Vivanco, J.M. Root secretion of defense-related proteins is development-dependent and correlated with flowering time. J. Biol. Chem. 2010, 285, 30654-30665. [CrossRef] [PubMed]

225. Kamilova, F.; Kravchenko, L.V.; Shaposhnikov, A.I.; Makarova, N.; Lugtenberg, B. Effects of the tomato pathogen fusarium oxysporum $\mathrm{f}$. Sp radicis-lycopersici and of the biocontrol bacterium pseudomonas fluorescens WCS365 on the composition of organic acids and sugars in tomato root exudate. Mol. Plant Microbe Interact. 2006, 19, 1121-1126. [CrossRef] [PubMed]

226. Scheffknecht, S.; St-Arnaud, M.; Khaosaad, T.; Steinkellner, S.; Vierheilig, H. An altered root exudation pattern through mycorrhization affecting microconidia germination of the highly specialized tomato pathogen fusarium oxysporum $\mathrm{f}$. Sp. Lycopersici (Fol) is not tomato specific but also occurs in Fol nonhost plants. Botany 2007, 85, 347-352.

227. Dzantor, E.K. Phytoremediation: The state of rhizosphere 'engineering' for accelerated rhizodegradation of xenobiotic contaminants. J. Chem. Technol. Biotechnol. 2007, 82, 228-232. [CrossRef]

228. Phillips, L.A.; Greer, C.W.; Farrell, R.E.; Germida, J.J. Plant root exudates impact the hydrocarbon degradation potential of a weathered-hydrocarbon contaminated soil. Appl. Soil Ecol. 2012, 52, 56-64. [CrossRef]

229. Joner, E.J.; Corgie, S.C.; Amellal, N.; Leyval, C. Nutritional constraints to degradation of polycyclic aromatic hydrocarbons in a simulated rhizosphere. Soil Biol. Biochem. 2002, 34, 859-864. [CrossRef]

230. Yoshitomi, K.J.; Shann, J.R. Corn (Zea mays 1.) root exudates and their impact on C-14-pyrene mineralization. Soil Biol. Biochem. 2001, 33, 1769-1776. [CrossRef]

231. Miya, R.K.; Firestone, M.K. Enhanced phenanthrene biodegradation in soil by slender oat root exudates and root debris. J. Environ. Qual. 2001, 30, 1911-1918. [CrossRef] [PubMed]

232. Da Silva, M.L.; Kamath, R.; Alvarez, P.J. Effect of simulated rhizodeposition on the relative abundance of polynuclear aromatic hydrocarbon catabolic genes in a contaminated soil. Environ. Toxicol. Chem. 2006, 25, 386-391. [CrossRef] [PubMed] 
233. Ling, W.; Dang, H.; Liu, J. In situ gradient distribution of polycyclic aromatic hydrocarbons (PAHS) in contaminated rhizosphere soil: A field study. J. Soils Sediments 2013, 13, 677-685. [CrossRef]

234. Corgie, S.C.; Beguiristain, T.; Leyval, C. Spatial distribution of bacterial communities and phenanthrene degradation in the rhizosphere of lolium perenne 1. Appl. Environ. Microbiol. 2004, 70, 3552-3557. [CrossRef] [PubMed]

235. Cébron, A.; Louvel, B.; Faure, P.; France-Lanord, C.; Chen, Y.; Murrell, J.C.; Leyval, C. Root exudates modify bacterial diversity of phenanthrene degraders in PAH-polluted soil but not phenanthrene degradation rates. Environ. Microbiol. 2011, 13, 722-736. [CrossRef] [PubMed]

236. Radwan, S.; Al-Awadhi, H.; Sorkhoh, N.; El-Nemr, I. Rhizospheric hydrocarbon-utilizing microorganisms as potential contributors to phytoremediation for the oil Kuwaiti desert. Microbiol. Res. 1998, 153, 247-251. [CrossRef]

237. Seo, J.-S.; Keum, Y.-S.; Hu, Y.; Lee, S.-E.; Li, Q.X. Phenanthrene degradation in arthrobacter sp. P1-1: Initial 1, 2-, 3, 4-and 9, 10-dioxygenation, and meta-and ortho-cleavages of naphthalene-1,2-diol after its formation from naphthalene-1,2-dicarboxylic acid and hydroxyl naphthoic acids. Chemosphere 2006, 65, 2388-2394. [CrossRef] [PubMed]

238. Kozdrój, J.; van Elsas, J.D. Response of the bacterial community to root exudates in soil polluted with heavy metals assessed by molecular and cultural approaches. Soil Biol. Biochem. 2000, 32, 1405-1417. [CrossRef]

239. Walton, B.T.; Anderson, T.A.; Guthrie, E.A. Bioremediation in the biosphere. Reply to comments. Environ. Sci. Technol. 1995, 29, 552. [CrossRef] [PubMed]

240. Kuiper, I.; Lagendijk, E.L.; Bloemberg, G.V.; Lugtenberg, B.J. Rhizoremediation: A beneficial plant-microbe interaction. Mol. Plant Microbe Interact. 2004, 17, 6-15. [CrossRef] [PubMed]

241. Kalbitz, K.; Schmerwitz, J.; Schwesig, D.; Matzner, E. Biodegradation of soil-derived dissolved organic matter as related to its properties. Geoderma 2003, 113, 273-291. [CrossRef]

242. Van Hees, P.A.W.; Jones, D.L.; Finlay, R.; Godbold, D.L.; Lundstomd, U.S. The carbon we do not see-The impact of low molecular weight compounds on carbon dynamics and respiration in forest soils: A review. Soil Biol. Biochem. 2005, 37, 1-13. [CrossRef]

243. Darrah, P.R. Models of the rhizosphere. I. Microbial-population dynamics around a root releasing soluble and insoluble carbon. Plant Soil 1991, 133, 187-199. [CrossRef]

244. Jones, D.L.; Murphy, D.V. Microbial response time to sugar and amino acid additions to soil. Soil Biol. Biochem. 2007, 39, 2178-2182. [CrossRef]

245. Dakora, F.D.; Phillips, D.A. Root exudates as mediators of mineral acquisition in low-nutrient environments. Plant Soil 2002, 245, 35-47. [CrossRef]

246. Rengel, Z.; Marschner, P. Nutrient availability and management in the rhizosphere: Exploiting genotypic differences. New Phytol. 2005, 168, 305-312. [CrossRef] [PubMed]

247. Marschner, P. Plant-microbe interactions in the rhizosphere and nutrient cycling. In Nutrient Cycling in Terrestrial Ecosystems; Marschner, P., Rengel, Z., Eds.; Springer: Berlin, Germany, 2007; Volume 10, pp. 159-182.

248. Singer, A. The chemical ecology of pollutant biodegradation: Bioremediation and phytoremediation from mechanistic and ecological perspectives. In Phytoremediation, Rhizoremediation; Mackova, M., Dowling, D., Macek, T., Eds.; Springer: Dordrecht, The Netherlands, 2006; Volume 9A, pp. 5-21.

249. Bais, H.P.; Broeckling, C.D.; Vivanco, J.M. Root exudates modulate plant-Microbe interactions in the rhizosphere. In Secondary metabolites in soil ecology; Karlovsky, P., Ed.; Springer: Berlin, Germany, 2008; Volume 14, pp. 241-252.

250. Kanaly, R.A.; Bartha, R. Cometabolic mineralization of benzo a pyrene caused by hydrocarbon additions to soil. Environ. Toxicol. Chem. 1999, 18, 2186-2190. [CrossRef]

251. Fletcher, J.S.; Hegde, R.S. Release of phenols by perennial plant-roots and their potential importance in bioremediation. Chemosphere 1995, 31, 3009-3016. [CrossRef]

252. Yergeau, E.; Sanschagrin, S.; Maynard, C.; St-Arnaud, M.; Greer, C.W. Microbial expression profiles in the rhizosphere of willows depend on soil contamination. ISME J. 2014, 8, 344-358. [CrossRef] [PubMed]

253. Cunningham, S.D.; Berti, W.R. Remediation of contaminated soil with green plants-An overview. In Vitro Cell. Dev. Biol. Plant 1993, 29P, 207-212. [CrossRef]

254. Ouvrard, S.; Lapole, D.; Morel, J. Root exudates impact on phenanthrene availability. Water Air Soil Pollut. Focus 2006, 6, 343-352. [CrossRef] 
255. Gao, Y.; Ren, L.; Ling, W.; Kang, F.; Zhu, X.; Sun, B. Effects of low-molecular-weight organic acids on sorption-desorption of phenanthrene in soils. Soil Sci. Soc. Am. J. 2010, 74, 51-59. [CrossRef]

256. Read, D.B.; Bengough, A.G.; Gregory, P.J.; Crawford, J.W.; Robinson, D.; Scrimgeour, C.M.; Young, I.M.; Zhang, K.; Zhang, X. Plant roots release phospholipid surfactants that modify the physical and chemical properties of soil. New Phytol. 2003, 157, 315-326. [CrossRef]

257. Siciliano, S.D.; Germida, J.J.; Banks, K.; Greer, C.W. Changes in microbial community composition and function during a polyaromatic hydrocarbon phytoremediation field trial. Appl. Environ. Microbiol. 2003, 69, 483-489. [CrossRef] [PubMed]

258. Xie, X.M.; Liao, M.; Yang, J.; Chai, J.J.; Fang, S.; Wang, R.H. Influence of root-exudates concentration on pyrene degradation and soil microbial characteristics in pyrene contaminated soil. Chemosphere 2012, 88, 1190-1195. [CrossRef] [PubMed]

259. LeFevre, G.H.; Hozalski, R.M.; Novak, P.J. Root exudate enhanced contaminant desorption: An abiotic contribution to the rhizosphere effect. Environ. Sci. Technol. 2013, 47, 11545-11553. [CrossRef] [PubMed]

260. Drever, J.I.; Stillings, L.L. The role of organic acids in mineral weathering. Colloids Surf. A 1997, 120, 167-181. [CrossRef]

261. Jones, D.L. Organic acids in the rhizosphere-A critical review. Plant Soil 1998, 205, 25-44. [CrossRef]

262. Jones, D.L.; Brassington, D.S. Sorption of organic acids in acid soils and its implications in the rhizosphere. Eur. J. Soil Sci. 1998, 49, 447-455. [CrossRef]

263. White, J.C.; Mattina, M.I.; Lee, W.Y.; Eitzer, B.D.; Iannucci-Berger, W. Role of organic acids in enhancing the desorption and uptake of weathered p,p'-DDE by cucurbita pepo. Environ. Pollut. 2003, 124, 71-80. [CrossRef]

264. Zhao, Z.-H.; Wang, L.-G.; Jiang, X.; Wang, F. Influence of three low-molecular-weight organic acids on the release behavior of Hchs from red soil. China Environ. Sci. 2006, 26, 324-327.

265. Ling, W.; Ren, L.; Gao, Y.; Zhu, X.; Sun, B. Impact of low-molecular-weight organic acids on the availability of phenanthrene and pyrene in soil. Soil Biol. Biochem. 2009, 41, 2187-2195. [CrossRef]

266. An, C.J.; Huang, G.H.; Yu, H.; Wei, J.; Chen, W.; Li, G. Effect of short-chain organic acids and pH on the behaviors of pyrene in soil-water system. Chemosphere 2010, 81, 1423-1429. [CrossRef] [PubMed]

267. Cao, L.; Wang, Q.; Zhang, J.; Li, C.; Yan, X.; Lou, X.; Xia, Y.; Hong, Q.; Li, S. Construction of a stable genetically engineered rhamnolipid-producing microorganism for remediation of pyrene-contaminated soil. World J. Microbiol. Biotechnol. 2012, 28, 2783-2790. [CrossRef] [PubMed]

268. Clifford, J.S.; Ioannidis, M.A.; Legge, R.L. Enhanced aqueous solubilization of tetrachloroethylene by a rhamnolipid biosurfactant. J. Colloid Interface Sci. 2007, 305, 361-365. [CrossRef] [PubMed]

269. Wang, Q.; Fang, X.; Bai, B.; Liang, X.; Shuler, P.J.; Goddard, W.A., III; Tang, Y. Engineering bacteria for production of rhamnolipid as an agent for enhanced oil recovery. Biotechnol. Bioeng. 2007, 98, 842-853. [CrossRef] [PubMed]

270. Cohan, F.M.; Koeppel, A.F. The origins of ecological diversity in prokaryotes. Curr. Biol. 2008, 18, R1024-U1017. [CrossRef] [PubMed]

271. Dagan, T.; Artzy-Randrup, Y.; Martin, W. Modular networks and cumulative impact of lateral transfer in prokaryote genome evolution. PNAS 2008, 105, 10039-10044. [CrossRef] [PubMed]

272. Gogarten, J.P.; Doolittle, W.F.; Lawrence, J.G. Prokaryotic evolution in light of gene transfer. Mol. Biol. Evol. 2002, 19, 2226-2238. [CrossRef] [PubMed]

273. De la Cruz, F.; Davies, J. Horizontal gene transfer and the origin of species: Lessons from bacteria. Trends Microbiol. 2000, 8, 128-133. [CrossRef]

274. Popa, O.; Dagan, T. Trends and barriers to lateral gene transfer in prokaryotes. Curr. Opin. Microbiol. 2011, 14, 615-623. [CrossRef] [PubMed]

275. Halary, S.; Leigh, J.W.; Cheaib, B.; Lopez, P.; Bapteste, E. Network analyses structure genetic diversity in independent genetic worlds. PNAS 2010, 107, 127-132. [CrossRef] [PubMed]

276. Zhang, M.; Pereira e Silva, M.C.; Chaib De Mares, M.; van Elsas, J.D. The mycosphere constitutes an arena for horizontal gene transfer with strong evolutionary implications for bacterial-fungal interactions. FEMS Microbiol. Ecol. 2014, 89, 516-526. [CrossRef] [PubMed]

277. Mela, F.; Fritsche, K.; Boersma, H.; van Elsas, J.D.; Bartels, D.; Meyer, F.; de Boer, W.; van Veen, J.A.; Leveau, J.H.J. Comparative genomics of the piPO2/pSB102 family of environmental plasmids: Sequence, evolution, and ecology of pTer331 isolated from collimonas fungivorans ter331. FEMS Microbiol. Ecol. 2008, 66, 45-62. [CrossRef] [PubMed] 
278. Thomas, C.M. Paradigms of plasmid organization. Mol. Microbiol. 2000, 37, 485-491. [CrossRef] [PubMed]

279. Li, X.B.; Top, E.M.; Wang, Y.F.; Brown, C.J.; Yao, F.; Yang, S.; Jiang, Y.; Li, H. The broad-host-range plasmid pSFA231 isolated from petroleum-contaminated sediment represents a new member of the pRoma plasmid family. Front. Microbiol. 2015, 5. [CrossRef] [PubMed]

280. Schluter, A.; Krause, L.; Szczepanowski, R.; Goesmann, A.; Puhler, A. Genetic diversity and composition of a plasmid metagenome from a wastewater treatment plant. J. Biotechnol. 2008, 136, 65-76. [CrossRef] [PubMed]

281. Rhodes, G.; Parkhill, J.; Bird, C.; Ambrose, K.; Jones, M.C.; Huys, G.; Swings, J.; Pickup, R.W. Complete nucleotide sequence of the conjugative tetracycline resistance plasmid pFBAOT6, a member of a group of IncU plasmids with global ubiquity. Appl. Environ. Microbiol. 2004, 70, 7497-7510. [CrossRef] [PubMed]

282. Ono, A.; Miyazaki, R.; Sota, M.; Ohtsubo, Y.; Nagata, Y.; Tsuda, M. Isolation and characterization of naphthalene-catabolic genes and plasmids from oil-contaminated soil by using two cultivation-independent approaches. Appl. Microbiol. Biotechnol. 2007, 74, 501-510. [CrossRef] [PubMed]

283. Molbak, L.; Molin, S.; Kroer, N. Root growth and exudate production define the frequency of horizontal plasmid transfer in the rhizosphere. FEMS Microbiol. Ecol. 2007, 59, 167-176. [CrossRef] [PubMed]

284. Droge, M.; Puhler, A.; Selbitschka, W. Horizontal gene transfer among bacteria in terrestrial and aquatic habitats as assessed by microcosm and field studies. Biol. Fertil. Soils 1999, 29, 221-245.

285. Jussila, M.M.; Zhao, J.; Suominen, L.; Lindstrom, K. Tol plasmid transfer during bacterial conjugation in vitro and rhizoremediation of oil compounds in vivo. Environ. Pollut. 2007, 146, 510-524. [CrossRef] [PubMed]

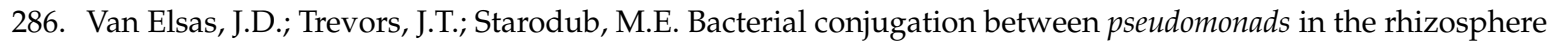
of wheat. FEMS Microbiol. Ecol. 1988, 53, 299-306. [CrossRef]

287. Van Elsas, J.D.; Turner, S.; Bailey, M.J. Horizontal gene transfer in the phytosphere. New Phytol. 2003, 157, 525-537. [CrossRef]

288. Kroer, N.; Barkay, T.; Sorensen, S.; Weber, D. Effect of root exudates and bacterial metabolic activity on conjugal gene transfer in the rhizosphere of a marsh plant. FEMS Microbiol. Ecol. 1998, 25, 375-384. [CrossRef]

289. Schwaner, N.E.; Kroer, N. Effect of plant species on the kinetics of conjugal transfer in the rhizosphere and relation to bacterial metabolic activity. Microb. Ecol. 2001, 42, 458-465. [CrossRef] [PubMed]

290. Nojiri, H.; Shintani, M.; Omori, T. Divergence of mobile genetic elements involved in the distribution of xenobiotic-catabolic capacity. Appl. Microbiol. Biotechnol. 2004, 64, 154-174. [CrossRef] [PubMed]

291. Ishida, T.; Kita, A.; Miki, K.; Nozaki, M.; Horiike, K. Structure and reaction mechanism of catechol 2,3-dioxygenase (metapyrocatechase). Int. Congr. Ser. 2002, 1233, 213-220. [CrossRef]

292. Wammer, K.H.; Peters, C.A. A molecular modeling analysis of polycyclic aromatic hydrocarbon biodegradation by naphthalene dioxygenase. Environ. Toxicol. Chem. 2006, 25, 912-920. [CrossRef] [PubMed]

293. Resnick, S.M.; Lee, K.; Gibson, D.T. Diverse reactions catalyzed by naphthalene dioxygenase from pseudomonas sp strain NCIB 9816. J. Ind. Microbiol. 1996, 17, 438-457. [CrossRef]

294. Parales, R.E.; Lee, K.; Resnick, S.M.; Jiang, H.Y.; Lessner, D.J.; Gibson, D.T. Substrate specificity of naphthalene dioxygenase: Effect of specific amino acids at the active site of the enzyme. J. Bacteriol. 2000, 182, 1641-1649. [CrossRef] [PubMed]

295. Li, W.; Shi, J.D.; Wang, X.G.; Han, Y.N.; Tong, W.; Ma, L.; Liu, B.; Cai, B.L. Complete nucleotide sequence and organization of the naphthalene catabolic plasmid PND6-1 from pseudomonas sp strain ND6. Gene 2004, 336, 231-240. [CrossRef] [PubMed]

296. Sentchilo, V.S.; Perebituk, A.N.; Zehnder, A.J.B.; van der Meer, J.R. Molecular diversity of plasmids bearing genes that encode toluene and xylene metabolism in pseudomonas strains isolated from different contaminated sites in belarus. Appl. Environ. Microbiol. 2000, 66, 2842-2852. [CrossRef] [PubMed]

297. Nielsen, K.M.; van Elsas, J.D. Stimulatory effects of compounds present in the rhizosphere on natural transformation of acinetobacter sp BD413 in soil. Soil Biol. Biochem. 2001, 33, 345-357. [CrossRef]

298. Yi, H.; Crowley, D.E. Biostimulation of PAH degradation with plants containing high concentrations of linoleic acid. Environ. Sci. Technol. 2007, 41, 4382-4388. [CrossRef] [PubMed]

299. Técher, D.; Laval-Gilly, P.; Henry, S.; Bennasroune, A.; Formanek, P.; Martinez-Chois, C.; D'Innocenzo, M.; Muanda, F.; Dicko, A.; Rejšek, K. Contribution of miscanthus $\times$ giganteus root exudates to the biostimulation of PAH degradation: An in vitro study. Sci. Total Environ. 2011, 409, 4489-4495. [CrossRef] [PubMed] 
300. Weyens, N.; Schellingen, K.; Beckers, B.; Janssen, J.; Ceulemans, R.; van der Lelie, D.; Taghavi, S.; Carleer, R.; Vangronsveld, J. Potential of willow and its genetically engineered associated bacteria to remediate mixed CD and toluene contamination. J. Soils Sediments 2013, 13, 176-188. [CrossRef]

301. Filonov, A.; Akhmetov, L.; Puntus, I.; Esikova, T.; Gafarov, A.; Izmalkova, T.Y.; Sokolov, S.; Kosheleva, I.; Boronin, A. The construction and monitoring of genetically tagged, plasmid-containing, naphthalene-degrading strains in soil. Microbiology 2005, 74, 453-458. [CrossRef]

302. Wang, Y.; Jiang, Q.; Zhou, C.; Chen, B.; Zhao, W.; Song, J.; Fang, R.; Chen, J.; Xiao, M. In-situ remediation of contaminated farmland by horizontal transfer of degradative plasmids among rhizosphere bacteria. Soil Use Manag. 2014, 30, 303-309.

(C) 2016 by the authors; licensee MDPI, Basel, Switzerland. This article is an open access article distributed under the terms and conditions of the Creative Commons by Attribution (CC-BY) license (http://creativecommons.org/licenses/by/4.0/). 